\title{
Potential Implications of Future Climate Change And Extremes On Health, Agriculture, Water, And Cryosphere Sectors In The Kabul River Basin
}

Kabi Raj Khatiwada ( $\sim$ kabirajkhatiwada@gmail.com )

ICIMOD: International Centre for Integrated Mountain Development https://orcid.org/0000-0002-88803013

\section{Saurav Pradhananga}

ICIMOD: International Centre for Integrated Mountain Development

\section{Santosh Nepal}

ICIMOD: International Centre for Integrated Mountain Development

\section{Research Article}

Keywords: Western Himalaya, Afghanistan, increasing temperature, warm days, climate change impact

Posted Date: July 13th, 2021

DOl: https://doi.org/10.21203/rs.3.rs-645615/v1

License: (a) (1) This work is licensed under a Creative Commons Attribution 4.0 International License. Read Full License 


\section{Abstract}

Increasing temperature and variability in precipitation are affecting different sectors in the Himalayan region. This study aims to quantify the future scenario and related extreme indices in the Kabul River Basin of the western Himalaya using high-resolution climate data sets. We selected the representative global climate model simulations for RCP4.5 and 8.5, based on their abilities to represent the historical climate cycle. By using a three-step methodology, we selected four models for RCP4.5 and four for RCP8.5. The analysis shows that, overall, precipitation will increase by 4 and 12 per cent for RCP 4.5 and 8.5 respectively by the end of the 21 st century, and the seasonal analysis shows decreasing pattern during the winter and pre-monsoon seasons. However, temperatures will increase consistently by $3^{\circ} \mathrm{C}$ to $5^{\circ} \mathrm{C}$ in RCP4.5 and 8.5 scenarios. The extreme indices were calculated based on the selected models. The extremes, like consecutive summer days, warm days, and heatwave will increase, whereas the frost days, cold nights, and cold waves will decrease towards the end of this century. Notably, more warm days and heatwaves than the baseline period are projected in future scenarios. Besides, the extremes are not homogenous in time and space. We also discussed the potential implications of these climatic extremes as related to human health, agricultural productivity, water availability, and the cryosphere. We strongly urge prompt climate actions in order to increase the adaptive capacity against these extreme changes and to build a resilient livelihood in the Kabul River Basin.

\section{Introduction}

Stressful climatological conditions, usually in the form of increased frequency and intensity of weather and climatic extremes, can affect the natural environment and the human system (Easterling et al. 2000). Climatic trends have been changing significantly in the Himalayan region (Vörösmarty, Green, Salisbury, and Lammers 2000), thereby influencing the availability of water (Barnett, Adam, and Lettenmaier 2005; Lutz, Immerzeel, Shrestha, and Bierkens 2014) and also having a bearing on the different components of the hydrological cycle (Hirabayashi et al. 2013) agriculture productivity (IPCC 2014a; Meresa, Romanowicz, and Napiorkowski 2017), human health (Seneviratne et al. 2012), and ecosystem services (IPCC 2014a; Meresa et al. 2017). This is likely to continue in the future affecting the Himalayan ecosystem and its functions (Huss and Hock 2018; IPCC 2014b; Parmesan, Root, and Willig 2000).

The variations and trends in these extreme climate events have recently received much attention, possibly due to more loss of lives and economic damages (Karl and Easterling 1999). The Special Report on Extreme Events (SREX) of the Intergovernmental Panel on Climate Change (IPCC) has highlighted their severe impacts on the society and the ecosystem (Murray and Ebi 2012). Likewise, the Expert Team on Sector-specific Climate Indices (ET-SCI) has developed sector-specific climate indices that aid in understanding the variability and trends in the climate and in characterizing the climate sensitivity of various sectors.

Many studies have discussed the sectoral implications of climatic extremes in a global context. Climate change and extreme weather events have a direct impact on human health (Epstein 1999; Wu, Lu, Zhou, 
Chen, and Xu 2016). The World Health Organization (WHO) estimates that every year about 150,000 deaths occur worldwide in low-income countries primarily due to the adverse effects of climate change; often the causes increase in vector-borne disease due to favourable temperatures, flood, crop failure, and extreme weather events (Kumaresan and Sathiakumar 2010). In the case of the agricultural sector, there have been significant reductions in crop yields due to change in soil quality and the menace of pests influencing pollination (Rosenzweig, Iglesius, Yang, Epstein, and Chivian 2001). This has been threatening national and regional food security (Nelson et al. 2009). Moreover, the dependence of agriculture on rainfall, snowmelt, and glacier melt - entities that have been adversely impacted by climate change has worsened the situation of food security and livelihoods. Meanwhile, the frequency, intensity, and duration of extreme water-related weather events such as excess precipitation, floods, and drought (Cann, Thomas, Salmon, Wyn-Jones, and Kay 2013) have altered the hydrological regime and the state of water availability, thereby increasing the demand for water for domestic and industrial purposes (Laghari, Vanham, and Rauch 2012). But not enough detailed studies in this regard have been conducted in the Himalayan region.

In the Hindu Kush Himalaya (HKH), as studies indicate, climatic extremes have been on the rise (Krishnan et al., 2019; Palazzi, Von Hardenberg, and Provenzale 2013). On a global scale, the Upper Indus Basin is the most important and vulnerable water tower (Immerzeel et al. 2020). As regards the Kabul River Basin (KRB), the westernmost tributary of the Indus River, studies on water availability have been conducted in the past by a few scholars (Hassanyar, Hassani, and Dozier 2017; Mack, Chornack, et al. 2010; Tünnermeier, Houben, and Himmelsbach 2005). Recent studies (Bokhari et al. 2018; Sidiqi, Shrestha, and Ninsawat 2018; Wi, Yang, Steinschneider, Khalil, and Brown 2015) in the same area point to an increase in temperature and variations in precipitation. The worsening climatic conditions in the region will continue to have an impact on socio-economic development, thereby causing even more stress for vulnerable groups (Savage, Dougherty, Hamza, and Bharwani 2009). Meanwhile, the transboundary issues and hydro-politics (Shroder and Ahmadzai 2016) around the Kabul River, in conjunction with changing climate, will amplify the uncertainty in water availability in the future; this will also affect the lives of the people living downstream, while there are global implications too.

The western Himalaya region has a poor understanding about the issue of climatic change and its effect on various sectors. This is worsened by the fact that the region is geographically challenging, which has translated into it having only a few observation stations (Bolch et al. 2012; Easterling, Evans et al. 2000; Wester, Mishra, Mukherji, and Shrestha 2019). So, often the information is generalized, and the few studies that have attempted to provide a detailed picture of the KRB have not been able to explicitly explain the reason behind selecting a particular global model for future projections. It is vital to conduct a detailed assessment while selecting a global model whereby its features, both in terms of time and space, are well understood (Shen et al. 2014); this is because these models are often influenced by the regional signals and their amplification (Boberg and Christensen 2012). This study has selected the global climate model runs based on the characteristics of the KRB. The study not only presents the future changes in the average precipitation and temperature patterns of the region, it also looks at the changes in extremes events in the basin and discusses its implications for health, agriculture, water, and the overall state of 
the cryosphere. The novelty of this study lies in its use of climatic extremes and linking them with sectoral implications for the KRB; for this, we used high-resolution climate data sets $(10 \times 10 \mathrm{~km})$ that reflect the regional characteristics; this is a method that has not been applied before.

\section{Methodological Approach}

This section describes the methodological approach that was taken for the selection of the Global Climate Model (GCM) runs specific to the KRB and outlines the sector-specific indices that were used for the analysis.

\subsection{Kabul River Basin}

The KRB is one of the main tributaries of the Indus River (Fig. 1). The Kabul River originates from the Sanglakh Range of the Hindu Kush mountains in Afghanistan and sustains the livelihoods of millions of people in both Afghanistan and Pakistan (Hassanyar et al. 2017). The KRB covers $69312 \mathrm{~km}^{2}$ and has an elevation range of $430-7,350$ masl, with 3 per cent of the area being above $5000 \mathrm{~m}$ asl. The basin is dominated by 60 per cent rangeland, while forests and shrubs constitute 18 per cent of the upstream area. Then there are the irrigated lands that are located downstream (Najmuddin, Deng, and Siqi 2017). The basin, where agriculture is the main source of livelihood, accounts for about 20 per cent of the total irrigated land in Afghanistan (Lashkaripour and Hussaini 2008).

The KRB is also the most populated area in Afghanistan. The northern part of the basin has mostly high mountains while the central and south-eastern parts are low agricultural lands (Lashkaripour and Hussaini 2008). The basin has $1,364 \mathrm{~km}^{2}$ of glaciers (2 per cent of the total area) and the region is mostly fed by snow and glacier melts. Water resources and the hydrological cycle act as important component in the sustainable development of the region (MeW 2019).

\subsection{The climatic conditions for the reference period}

The annual average precipitation sum of the basin is $722 \mathrm{~mm} /$ year (1981-2010), with February, March, and April being the months with the highest precipitation rates. The pre-monsoon season records the highest precipitation of $311 \mathrm{~mm}$ (43 per cent of the total), while the post-monsoon season, with $92 \mathrm{~mm}$ (12.8 per cent of the total), records the lowest level of precipitation. The precipitation amount, frequency, and intensity vary spatially and influences the local weather. The spatial graph (Fig. 2) shows that the precipitation level ranges from $200 \mathrm{~mm}$ (central and north-eastern parts) to $1600 \mathrm{~mm}$ (northern part), and is more ( $>1000 \mathrm{~mm} /$ year) in the northern part of the basin (especially in the $35^{\circ} \mathrm{N}-36^{\circ} \mathrm{N}$ latitude). The precipitation levels vary highly in the winter months, with the highest variability being in March.

The mean annual temperature of the basin is $1^{\circ} \mathrm{C}$; however, the mean monthly average temperature drops to $-10^{\circ} \mathrm{C}$ in December and January, while it increases to as high as $15^{\circ} \mathrm{C}$ in July and August. Inevitably, the summer season shows the highest temperature $\left(10.4^{0} \mathrm{C}\right)$, while the lowest $\left(-9.3^{0} \mathrm{C}\right)$ is during the winter 
season. Spatially, the temperature is higher $\left(>3^{0} \mathrm{C} /\right.$ year) in the southern part (below $\left.35^{\circ} \mathrm{N}\right)$ of the basin (Fig. 2). The average monthly temperature shows similar variability throughout the year.

This study considered the regional data set prepared for the Himalayan Adaptation, Water and Resilience (HI-AWARE) Research (Lutz et al. 2014) as its reference data set. This data set on the average climatic condition of the basin shows the optimal precipitation and temperature ranges during the baseline period. This information helps in learning more about human adaptability in terms of precipitation and temperature ranges; it also provides a clear-cut picture about the climatic conditions that help support agricultural productivity; further, it gives us the baseline of water availability and the cryospheric condition.

\subsection{Selection of the Global Circulation Model}

In this study, we looked into two different climate change scenarios, RCP4.5 and RCP8.5, in order to understand the future scenario of the KRB. RCP4.5 describes a middle-range mitigation emission scenario, which assumes that the increase in radiative forcing will stabilize at $4.5 \mathrm{~W} / \mathrm{m}^{2}$ in 2100 , while RCP8.5 corresponds to the pathway with the highest greenhouse gas emission scenario, which assumes that an increase in radiative forcing will stabilize at $8.5 \mathrm{~W} / \mathrm{m}^{2}$ in 2100 (Van Vuuren et al. 2011). RCP2.6, which is the optimistic scenario, requires a drastic and immediate reduction in fossil fuel consumption. This does not seem plausible under the present condition of emissions in the world. As for the RCP6 scenario, it was not considered as it lies within the spectrum of the future scenarios of RCP4.5 and RCP8.5. Thus, based on these scenarios, the potential impact of extreme climate indices on four different sectors - health, agriculture, water resources, and the cryosphere - were studied.

There is great variability in the projections of precipitation and temperature made by different Global Circulation Models (GCMs). A total of 105 GCM runs for RCP4.5 and 77 for RCP8.5 from the Coupled Model Intercomparison Project (CMIP5) experimental design were considered for this study. Each GCM run and ensembles has represented atmospheric circulation differently, based on their physics, realization, and initialization; they have also represented the regional climatic conditions differently (Bader et al. 2008). To select the GCM runs that represent the study area, a three-step selection procedure integrating the envelope-based and past-performance approaches was used, as suggested by Lutz et al. (2016). This approach was also used for the National Adaptation Plan (MoFE 2019) as well as to understand future climate scenarios (Kaini, Nepal, Pradhananga, Gardner, and Sharma 2019). The following were the three steps:

- In the first step, the changes in the annual mean air temperature $(\Delta T)$ and annual precipitation sum $(\Delta \mathrm{P})$ between 1981-2100 and 2071-2100 were calculated over the area of interest of all GCM runs. The distribution of change values provided four different spectra of possible climatic conditions: warm-dry, warm-wet, cold-dry, and cold-wet. Five models from each corner (from 20 GCM runs) were selected based on projections of temperature and precipitation change for both RCPs. Here, only those models that had data available at a daily time-step were selected. 
- In the second step, the 20 model runs obtained from the first step were reduced to eight models, based on their projected changes in climatic extremes for both RCPs. Here, two climate change indices for both air temperature and precipitation were used (Peterson 2005). For temperature, the Warm Spell Duration Index (WSDI) and the Cold Spell Duration Index (CSDI) were analysed, while for the precipitation, the number of extremely wet days (R95pTOT) and Consecutive Dry Days (CDD) were considered. The percentage changes in the indices were calculated for 2071-2100 using the reference period of 1981-2010.

- In the third step, the final selection of four GCM runs for each scenario was based on the skill of these models represent the historical climate cycle (from 1981-2010) using reference data sets.. The regional data set prepared for the HI-AWARE Research ( Lutz et al. 2014) was considered as the reference data set, and summer, winter, and annual biases were considered for the analysis of both precipitation and temperature. Specifically, we considered winter precipitation since the study area gets the majority of its precipitation during this season.

\subsection{Sector-specific climatic indices}

We chose 10 extreme indices to indicate the implications for the sectors of health, agriculture, water resources, and the cryosphere, as defined by the ET-SCI (Expert Team on Sector-Specific Climate Indices). Some indices were applied to more than one sector (Table 1). For our analysis, we selected six indices for water resources (that included the cryosphere), nine for agriculture, and nine for the health sector. In the result section, the two opposite extremes indices are presented together for efficient visualization and understanding. 
Table 1

List of extreme indices and their implications for the different sectors.

\begin{tabular}{|c|c|c|c|c|c|c|c|}
\hline \multirow[t]{2}{*}{ Name (Unit) } & \multirow[t]{2}{*}{ Indices } & \multirow[t]{2}{*}{ Details } & \multirow{2}{*}{$\begin{array}{l}\text { Climatic } \\
\text { Variables }\end{array}$} & \multicolumn{4}{|l|}{ Sectors } \\
\hline & & & & Health & Agriculture & Water & Cryosphere \\
\hline $\begin{array}{l}\text { Consecutive } \\
\text { Summer } \\
\text { Days } \\
\text { (days/year) }\end{array}$ & CSU & $\begin{array}{l}\text { Consecutive } \\
\text { days when } \\
\text { the } \\
\text { maximum } \\
\text { temperature } \\
\text { exceeds } 6^{\circ} \mathrm{C}\end{array}$ & Tmax & प & & & \\
\hline $\begin{array}{l}\text { Consecutive } \\
\text { Frost Days } \\
\text { (days/year) }\end{array}$ & CFD & $\begin{array}{l}\text { Consecutive } \\
\text { days when } \\
\text { the } \\
\text { minimum } \\
\text { temperature } \\
\text { is below } 0^{\circ} \mathrm{C}\end{array}$ & Tmin & प & प & & Q \\
\hline $\begin{array}{l}\text { Heatwave } \\
\text { Duration } \\
\text { Index } \\
\text { (days/year) }\end{array}$ & HWDI & $\begin{array}{l}\text { The annual } \\
\text { length of the } \\
\text { longest heat } \\
\text { wave }\end{array}$ & Tmax & $\square$ & प & प & Q \\
\hline $\begin{array}{l}\text { Cold Wave } \\
\text { Duration } \\
\text { Index } \\
\text { (days/year) }\end{array}$ & CWDI & $\begin{array}{l}\text { The annual } \\
\text { length of the } \\
\text { longest cold } \\
\text { wave }\end{array}$ & Tmin & प & प & ए & Q \\
\hline $\begin{array}{l}\text { Warm days } \\
\text { (days/year) }\end{array}$ & TG90P & $\begin{array}{l}\text { The annual } \\
\text { count of } \\
\text { consecutive } \\
\text { days with an } \\
\text { average } \\
\text { temperature } \\
\text { greater than } \\
\text { the } 90 \text { th } \\
\text { percentile }\end{array}$ & Tavg & $\square$ & ૫ & & \\
\hline $\begin{array}{l}\text { Cold nights } \\
\text { (days/year) }\end{array}$ & TN10P & $\begin{array}{l}\text { The annual } \\
\text { count of } \\
\text { consecutive } \\
\text { days with } \\
\text { minimum } \\
\text { temperature } \\
\text { less than the } \\
\text { 10th } \\
\text { percentile }\end{array}$ & Tmin & $\square$ & ૫ & & \\
\hline $\begin{array}{l}\text { Consecutive } \\
\text { Dry Days } \\
\text { (days/year) }\end{array}$ & CDD & $\begin{array}{l}\text { Maximum } \\
\text { number of } \\
\text { Consecutive } \\
\text { Dry Days } \\
\text { (when PR < } \\
1.0 \mathrm{~mm} \text { ) }\end{array}$ & Precip & प & प & प & \\
\hline
\end{tabular}




\begin{tabular}{|c|c|c|c|c|c|c|c|}
\hline \multirow[t]{2}{*}{ Name (Unit) } & \multirow[t]{2}{*}{ Indices } & \multirow[t]{2}{*}{ Details } & \multirow{2}{*}{$\begin{array}{l}\text { Climatic } \\
\text { Variables }\end{array}$} & \multicolumn{4}{|l|}{ Sectors } \\
\hline & & & & Health & Agriculture & Water & Cryosphere \\
\hline $\begin{array}{l}\text { Consecutive } \\
\text { Wet Days } \\
\text { (days/year) }\end{array}$ & CWD & $\begin{array}{l}\text { The } \\
\text { maximum } \\
\text { annual } \\
\text { number of } \\
\text { consecutive } \\
\text { wet days } \\
\text { (when PR > = } \\
1.0 \mathrm{~mm} \text { ) }\end{array}$ & Precip & प & प & Q & \\
\hline $\begin{array}{l}\text { Very high } \\
\text { precipitation } \\
\text { days } \\
\text { (days/year) }\end{array}$ & $\begin{array}{l}\text { RGT90P } \\
\text { (eca } \\
\text { r5mm) }\end{array}$ & $\begin{array}{l}\text { Number of } \\
\text { days when } \\
\text { precipitation } \\
\text { is greater } \\
\text { than the } \\
\text { 90th } \\
\text { percentile }\end{array}$ & Precip & & प & $\square$ & \\
\hline $\begin{array}{l}\text { Very low } \\
\text { precipitation } \\
\text { days } \\
\text { (days/year) }\end{array}$ & $\begin{array}{l}\text { RLT10P } \\
\text { (eca } \\
\text { r1mm) }\end{array}$ & $\begin{array}{l}\text { Number of } \\
\text { days when } \\
\text { precipitation } \\
\text { is less than } \\
\text { the } 10 \\
\text { percentile }\end{array}$ & Precip & $\nabla f$ & $\square$ & $\square$ & \\
\hline
\end{tabular}

Consecutive Summer Days (CSU) and Consecutive Frost Days (CFD) reflect the heat and cold indices of the area. CSU is counted as the maximum number of consecutive days when the maximum temperature is greater than the average daily maximum temperature, $6.2^{\circ} \mathrm{C}$ for the KRB. Similarly, CFD is the maximum number of consecutive days with a daily minimum temperature of less than $0^{\circ} \mathrm{C}$.

The HWDI and the CWDI, with respect to the mean of the reference period, reflect excessive heat days or excessive cold days. The HWDI shows the number of consecutive days when the daily maximum temperature (TX) is greater than the mean (a five-day window centred on each calendar day) of the daily maximum temperature of the reference period (TXnorm) and the temperature offset (T) (i.e., HWDI = TX > $T X n o r m+T)$. More than 6 consecutive days are considered and the offset temperature is taken as $5^{\circ} \mathrm{C}$. Likewise, the CWDI indicates the number of days when: TN $<$ TNnorm - T. Here, TN is the daily minimum temperature, TNnorm is the mean of the minimum temperatures of a given climate reference period (i.e., 1981-2010).

Warm days with respect to the 90th percentile of the reference period (TG90P) and cold nights with respect to the 10th percentile of the reference period (TN10P) help in understanding the sensitivity of the day and night-time temperatures in the KRB. To calculate the warm days, the percentage of warm days with respect to the 90th percentile of the daily mean temperatures of a five-day window centred on each calendar day of the reference period (1981-2010) was calculated. Likewise, for calculating the cold nights, the percentage of cold days with respect to the 10th percentile of the daily minimum temperatures 
of a five-day window centred on each calendar day of the reference period (1981-2010) was calculated. The percentage was then converted to the number of days per year by multiplying by 3.65 .

CDD and CWD reflect the dryness and wetness of an area. CDD is the maximum number of consecutive precipitation days with less than $1 \mathrm{~mm}$ during a year. Likewise, CWD is the maximum number of consecutive precipitation days greater than $1 \mathrm{~mm}$ during a year. In the visualization, the annual change is presented spatially to show the projected changes in the different areas of the basin. These two indices indicate whether there will be more dryness or wetness in the future.

Very high precipitation (RGT90P) and very low precipitation (RLT10P) reflect the extremes of precipitation. RGT90P is the number of days when the daily precipitation amount is more than the 90th percentile of the daily average precipitation. For this, at first, the 90th percentile precipitation was calculated ( $5^{\prime} \mathrm{mm}$ for KRB); then this value was used to calculate the number of days with precipitation of at least more than $5 \mathrm{~mm}$ for the annual time series of the daily precipitation. Likewise, for very low precipitation, the threshold of the 10th percentile of precipitation $(1 \mathrm{~mm})$ was used. Based on this value, the number of days with a maximum of $1 \mathrm{~mm}$ of precipitation was counted.

\section{Results}

\subsection{Selection of the GCMs}

Figure 3 shows the projected changes in temperature and precipitation from the reference period (1981$2010)$ to the end of the century (2071-2100). The figure shows that the temperature would rise in the range of $3-10^{\circ} \mathrm{C}$ and the precipitation would increase in the range of $0-50$ per cent. From this first step, five GCM runs were selected from each corner, and altogether, $20 \mathrm{GCMs}$ were selected. This corner represents four possible future climates: warm-dry, warm-wet, cold-wet, and cold-dry.

Table 2 shows the selected 20 model runs that were selected from step 1 and how these model runs were filtered up to step 3 . Table $2 a$ shows the values of the climate change indices of the 20 models. From step 2, 12 model runs in RCP4.5 and eight in RCP8.5 were further selected. These were the model runs that showed the highest change in extreme values by the end of the century.

Table 2: The detailed steps: Upper 2a - steps 1 and 2; lower 2b - step 3); for the selection of the GCM at each corner after $20 \mathrm{GCMs}$ were selected for each RCP. 


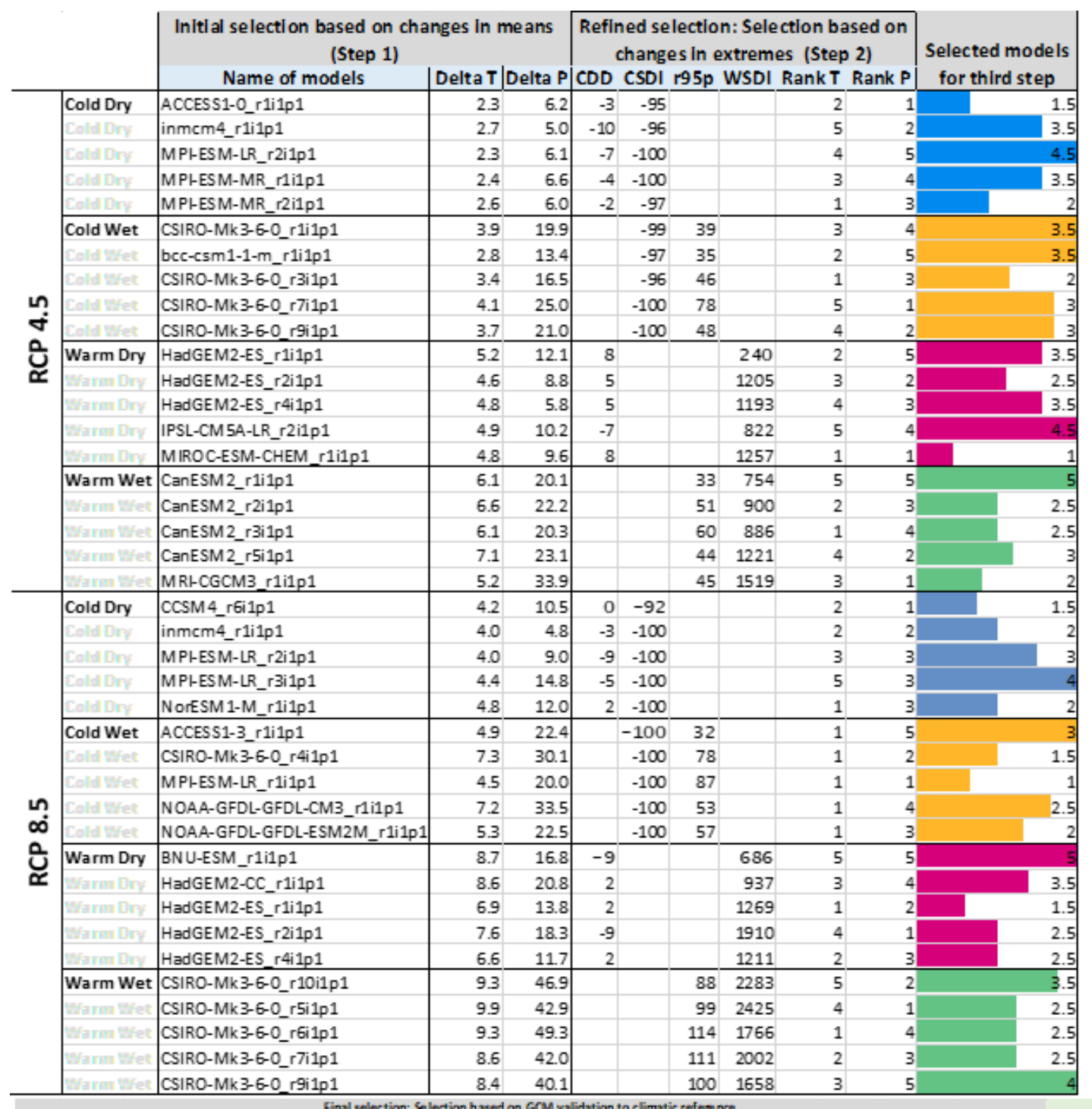

\begin{tabular}{|c|c|c|c|c|c|c|c|c|c|c|c|c|c|c|}
\hline \multicolumn{14}{|c|}{$\begin{array}{l}\text { Final selection: Selection based on GCOM validation to climatic refere nce } \\
\qquad \text { [Step 3] }\end{array}$} & \multirow{2}{*}{$\begin{array}{l}\text { Selected model } \\
\text { based on } \\
\text { combined scare }\end{array}$} \\
\hline & & Name of the models & \begin{tabular}{|l|} 
Precipitation bias \\
Annual|Winter \\
\end{tabular} & \multicolumn{3}{|c|}{$\begin{array}{c}\text { Temperature bias } \\
\text { Annus | Monsoon } / \text { Winter }\end{array}$} & 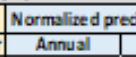 & $\begin{array}{l}\text { pittation bias } \\
\text { Winter } \\
\end{array}$ & \multicolumn{3}{|c|}{ Normolized temperature bis } & \begin{tabular}{|l} 
Precipititio \\
in biss score
\end{tabular} & \begin{tabular}{|c|c|}
$\begin{array}{c}\text { Temperature } \\
\text { bias scoore }\end{array}$ \\
\end{tabular} & \\
\hline \multirow{12}{*}{$\begin{array}{l}\text { nn } \\
\dot{t} \\
\dot{q}\end{array}$} & $\cos \mathrm{der}_{\mathrm{y}}$ & rmom4 nalipl 1 & $\begin{array}{ll}9.8 & 31.4 \\
\end{array}$ & 1.0 & 41 & & 0.21 & 0.41 & 0.07 & 0.41 & 0.12 & 0.31 & & \\
\hline & & VPIESW LR RAIPI & 1.0 & 0.5 & 25 & 51 & 0.02 & 0.29 & 0.04 & 0.25 & 0.22 & 016 & 0.17 & \\
\hline & 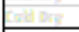 & VPI ESW NR rIIp1 & $1.2 \quad 27.6$ & 0.4 & 26 & 50 & 003 & 0.36 & 0.01 & 0.26 & 0.22 & 0.19 & 0.17 & 0.36 \\
\hline & cold Wat & 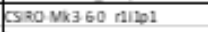 & $\begin{array}{lll}4.9 & \pi 6.1 \\
\end{array}$ & 14.5 & 97 & 230 & 097 & 0.99 & $1 . \infty$ & 0.98 & 100 & 099 & 0.99 & 1.97 \\
\hline & & $\operatorname{coc} \operatorname{sen} 1$ & 30.8 & 6.4 & 62 & 7.9 & 067 & 0.76 & 0.4 & 0.62 & 0.34 & a.7 & 0.47 & \\
\hline & & Esao Nx & 45.6 & 14.4 & .98 & 228 & 099 & 1.00 & d 1.00 & 0.99 & 099 & 099 & & \\
\hline & 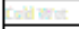 & 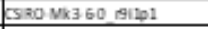 & 46.2 & 14.2. & 99 & 224 & 100 & 0.98 & 0.9 & 1.00 & 097 & 099 & 0.99 & \\
\hline & Warm on & 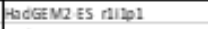 & 6.0 & 1.6 & 33 & ag & 0.13 & 0.39 & 0.11 & 0.33 & 0,04 & 0.26 & 0.16 & $\overline{0.42}$ \\
\hline & & 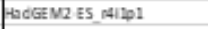 & 2.2 & 1.1 & 29 & 19 & 0.05 & 0.39 & 0.07 & 0.29 & 008 & 0.22 & 0.15 & \\
\hline & & PS. CNGA LR r21Pl & $\begin{array}{l}31.3 \\
\end{array}$ & 7.2 & .55 & 90 & 068 & 0.91 & 0.50 & 0.55 & 0.39 & 080 & 0.48 & \\
\hline & WarmWes & Canesv2 n11p1 & & 2.7 & 25 & 30 & 0.82 & 0.82 & \begin{tabular}{|l|l|}
2 & 0.19 \\
\end{tabular} & 0.25 & 0.13 & 0.82 & 0.19 & \\
\hline & & Eanesv2 rsilp1 & 40.6 & 4.0 & 30 & 63 & 088 & 0.83 & 0.27 & 0.30 & 0.27 & 086 & 0.28 & \\
\hline \multirow{8}{*}{$\begin{array}{l}n \\
\infty \\
0 \\
\bar{z}\end{array}$} & $\cos d \operatorname{der}^{2}$ & VPI ESN LR ra1pL & 22.1 & 0.5 & 25 & & & 0.28 & 4 & 0.25 & 0.21 & 0.15 & 0.16 & 0.32 \\
\hline & & VPI ESW LR r r31pl & $1.2 \quad 27.6$ & 0.4 & 26 & 50 & 003 & 0.35 & 0.0 & 026 & 0.20 & 0.19 & 0.16 & \\
\hline & cod Wat & accessi a n: & .34.3 & 0.6 & 33 & 33 & 020 & 0.43 & 0.04 & 0.33 & 0.14 & 0.32 & 0.17 & \\
\hline & & YOA A GFO & $22.5 \quad 45.6$ & 1.7. & 49 & 36 & 0.48 & 0.58 & 0.11 & 0.49 & 015 & 0.53 & & \\
\hline & Warm on & Non Es: & 22.5 & 5.0 & 49 & 52 & 0.07 & 0.29 & 0.34 & 0.49 & 021 & 018 & 0.35 & \\
\hline & & tadoen & $11.9 \quad 41.9$ & 4.2. & 48 & 11) & 0.25 & 0.52 & $\begin{array}{l}2.28 \\
\end{array}$ & 0.48 & 0.13 & 0.39 & 0.30 & \\
\hline & WarmWea & $320 \mathrm{~N} \times 3.60$ r1012p1 & \begin{tabular}{|l|l|}
46.7 & 78.8 \\
\end{tabular} & 14.9 & 100 & 245 & 100 & 1.00 & $1 . \infty$ & 100 & 100 & 100 & 100 & $2 . x$ \\
\hline & tama & 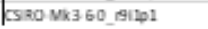 & $\begin{array}{lll}46.9 & -75.0\end{array}$ & 14.5 & 99 & 223 & 100 & 0.95 & \$ 0.97 & 0.99 & 091 & 098 & 0.96 & 1.9 \\
\hline
\end{tabular}

Table $2 \mathrm{~b}$ shows the seasonal and annual biases of temperature and precipitation that were applied in the third step. The temperature and precipitation biases of summer and winter were calculated - to reflect the seasonal dynamics. The lowest bias models, i.e. models which better represent the historical cycles, were selected as the final models at each corner of each RCP. The details of the selected models are presented in Table 3. 
Table 3

The description of the selected GCMs.

\begin{tabular}{|c|c|c|c|c|}
\hline & Selected GCM & $\begin{array}{l}\text { Description } \\
\text { (corner) }\end{array}$ & $\begin{array}{l}\text { Atmospheric } \\
\text { Grid } \\
\text { (latitude x } \\
\text { longitude) }\end{array}$ & Institute \\
\hline \multirow[t]{4}{*}{ RCP4.5 } & MPI-ESM_LR_r2i1p1 & Cold-Dry & $1.86 \times 1.87$ & $\begin{array}{l}\text { Max-Planck-Institut für } \\
\text { Meteorologie, Germany }\end{array}$ \\
\hline & $\begin{array}{l}\text { BCC-CSM1-1- } \\
\text { m_r1i1p1 }\end{array}$ & Cold-Wet & $2.79 \times 2.81$ & $\begin{array}{l}\text { Beijing Climate Center Climate } \\
\text { System Model 1.1, China } \\
\text { Meteorological Administration, } \\
\text { China }\end{array}$ \\
\hline & HadGEM2_ES_r4i1p1 & Warm-Dry & & Met Office Hadley Centre, UK \\
\hline & CanESM2_r1i1p1 & Warm-Wet & $2.79 \times 2.81$ & $\begin{array}{l}\text { The Second Generation Canadian } \\
\text { Earth System Model, Canadian } \\
\text { Centre for Climate Modeling and } \\
\text { Analysis, Canada }\end{array}$ \\
\hline \multirow[t]{4}{*}{ RCP8.5 } & MPI-ESM_LR_r2i1p1 & Cold-Dry & $1.86 \times 1.87$ & $\begin{array}{l}\text { Max-Planck-Institut für } \\
\text { Meteorologie, Germany }\end{array}$ \\
\hline & ACCESS1-3_r1i1p1 & Cold-Wet & $1.25 \times 1.87$ & $\begin{array}{l}\text { Australian Community Climate and } \\
\text { Earth System Simulator } 1.3\end{array}$ \\
\hline & BNU-ESM_r1i1p1 & Warm-Dry & $2.79 \times 2.81$ & $\begin{array}{l}\text { Beijing Normal University Earth } \\
\text { System Model, China }\end{array}$ \\
\hline & $\begin{array}{l}\text { CSIRO_Mk3-6- } \\
\text { 0_r9i1p1 }\end{array}$ & Warm-Wet & $1.86 \times 1.87$ & $\begin{array}{l}\text { Australian Commonwealth } \\
\text { Scientific and Industrial Research } \\
\text { Organization in collaboration with } \\
\text { the Queensland Climate Change } \\
\text { Centre of Excellence, Australia }\end{array}$ \\
\hline
\end{tabular}

\subsection{The future scenario of temperature and precipitation in the basin}

The temperature of the KRB is projected to increase by $2.7^{\circ} \mathrm{C}$ in RCP4.5 and by $5.1^{\circ} \mathrm{C}$ in RCP 8.5 scenarios, and the precipitation is projected to increase by 4.5 per cent in RCP 4.5 and by 12.4 per cent in RCP8.5 compared to the reference period (Fig. 4).

Table 4 shows that all the eight models signify increasing temperature in both scenarios. The standard deviation among the models in terms of temperature change is low $\left(1.44^{\circ} \mathrm{C}\right)$ with a coefficient of variation of 37 per cent. However, there is higher variability in future precipitation scenarios in the basin. On an average, while the precipitation pattern indicates an increase, some models show a decreasing scenario in RCP4.5. Therefore, there is comparatively higher standard deviation (16.8 per cent) and a coefficient of 
variation (201 per cent) in precipitation than in temperature. Similar results can be seen in other studies carried out on temperature (Bokhari et al. 2018; Ghulami 2017; Hashmi et al. 2020) and precipitation (Mack, Akbari et al. 2010; NEPA and UNEP 2015) in the basin.

Table 4

Temperature and precipitation changes in future scenarios.

\begin{tabular}{|llllll|}
\hline & & \multicolumn{2}{c}{ Change in Temperature $\left({ }^{\circ} \mathrm{C}\right)$} & \multicolumn{2}{c|}{ Change in Precipitation (\%) } \\
\cline { 2 - 6 } RCP4.5 & Name of the Model & $\mathbf{2 0 3 5 - 2 0 6 5}$ & $\mathbf{2 0 7 1 - 2 1 0 0}$ & $\mathbf{2 0 3 5 - 2 0 6 5}$ & $\mathbf{2 0 7 1 - 2 1 0 0}$ \\
& MPI-ESM_rcp45_r2i1p1 & 2.1 & 2.46 & -21 & -11.95 \\
\cline { 2 - 6 } & BCC-CSM1m_rcp45_r1i1p1 & 1.6 & 1.62 & -8.2 & 8.1 \\
\hline HADGEM2_rcp45_r4i1p1 & 2.66 & 3.61 & 2.14 & 8.2 \\
\hline CanESM2_rcp45_r1i1p1 & 2.41 & 3.08 & 14.31 & 13.69 \\
\hline RCP8.5 & Average & 2.19 & 2.69 & -3.19 & 4.51 \\
\cline { 2 - 5 } & ACCESS_ESM_rcp85_r2i1p1 & 2.55 & 5.07 & -4.32 & -17.12 \\
\hline BNU-ESM_rcp85_r1i1p1 & 2.65 & 4.8 & 6.73 & 21.16 \\
\hline CSIRO_rcp85_r9i1p1 & 3.08 & 5.65 & 17.29 & 3.69 \\
\hline Average & 2.73 & 5.13 & 6.57 & 12.27 \\
\hline Total average & 2.46 & 3.91 & 1.69 & 8.39 \\
\hline Standard deviation & 0.44 & 1.44 & 12.54 & 16.83 \\
\hline Coefficient of variation & $18 \%$ & $37 \%$ & $743 \%$ & $201 \%$ \\
\hline
\end{tabular}

The seasonal projection shows that the temperature of the basin will increase more in the winter and post-monsoon seasons, followed by monsoon (Table 5). There will be less precipitation in winter during RCP4.5, while in RCP8.5, it will decrease both in the winter and pre-monsoon seasons. This is similar to what has been found by other studies on the future scenario: Bokhari et al. (2018) highlight a decrease in precipitation by up to 50 per cent in the winter season (December to March); and Shroder et al. (2016) highlight a decrease in monsoon precipitation by 20 per cent in Pakistan and southeastern Afghanistan. These changes in the seasonal precipitation pattern is likely to increase the water stress in the KRB (Siddiqui et al. 2019). 
Future scenarios of seasonal changes in precipitation and temperature.

\begin{tabular}{|c|c|c|c|c|c|}
\hline \multirow[t]{3}{*}{ Seasons } & \multirow[t]{3}{*}{$\begin{array}{l}\text { Average temperature (1981- } \\
2010)\left({ }^{\circ} \mathrm{C}\right)\end{array}$} & \multicolumn{4}{|c|}{$\begin{array}{l}\text { Change in Temperature }\left({ }^{\circ} \mathrm{C}\right) \text { (Standard } \\
\text { Deviation) }\end{array}$} \\
\hline & & \multicolumn{2}{|l|}{ RCP4.5 } & \multicolumn{2}{|l|}{ RCP8.5 } \\
\hline & & $\begin{array}{l}2036- \\
2065\end{array}$ & $\begin{array}{l}2071- \\
2100\end{array}$ & $\begin{array}{l}2036- \\
2065\end{array}$ & $\begin{array}{l}2071- \\
2100\end{array}$ \\
\hline Winter (Dec-Feb) & -9.33 & $\begin{array}{l}2.69 \\
(0.42)\end{array}$ & $\begin{array}{l}3.34 \\
(0.78)\end{array}$ & $\begin{array}{l}3.3 \\
(0.46)\end{array}$ & $\begin{array}{l}5.88 \\
(0.51)\end{array}$ \\
\hline $\begin{array}{l}\text { Pre-monsoon } \\
\text { (Mar- May) }\end{array}$ & -0.42 & $\begin{array}{l}1.86 \\
(1.09)\end{array}$ & $\begin{array}{l}1.8 \\
(1.71)\end{array}$ & $\begin{array}{l}1.1 \\
(1.66)\end{array}$ & $\begin{array}{l}2.88 \\
(2.16)\end{array}$ \\
\hline $\begin{array}{l}\text { Monsoon (Jun- } \\
\text { Aug) }\end{array}$ & 10.42 & $\begin{array}{l}1.87 \\
(0.67)\end{array}$ & $\begin{array}{l}2.32 \\
(1.37)\end{array}$ & $\begin{array}{l}2.28 \\
(1.02)\end{array}$ & $\begin{array}{l}4.38 \\
(1.75)\end{array}$ \\
\hline $\begin{array}{l}\text { Post-monsoon } \\
\text { (Sep-Nov) }\end{array}$ & 3.08 & $\begin{array}{l}2.21 \\
(1.52)\end{array}$ & $\begin{array}{l}3.17 \\
(2.1)\end{array}$ & $\begin{array}{l}4.16 \\
(1.6)\end{array}$ & $7.3(2.62)$ \\
\hline Annual Average & 1 & $\begin{array}{l}2.16 \\
(0.93)\end{array}$ & $\begin{array}{l}2.66 \\
(1.49)\end{array}$ & $\begin{array}{l}2.71 \\
(1.185)\end{array}$ & $\begin{array}{l}5.11 \\
(1.76)\end{array}$ \\
\hline \multirow[t]{3}{*}{ Seasons } & \multirow[t]{3}{*}{$\begin{array}{l}\text { Precipitation (1981-2010) } \\
\text { (percentage) }\end{array}$} & \multicolumn{4}{|c|}{$\begin{array}{l}\text { Change in Precipitation (\%) (Standard } \\
\text { Deviation) }\end{array}$} \\
\hline & & \multicolumn{2}{|l|}{ RCP4.5 } & \multicolumn{2}{|l|}{ RCP8.5 } \\
\hline & & $\begin{array}{l}2036- \\
2065\end{array}$ & $\begin{array}{l}2071- \\
2100\end{array}$ & $\begin{array}{l}2036- \\
2065\end{array}$ & $\begin{array}{l}2071- \\
2100\end{array}$ \\
\hline Winter (Dec-Feb) & 219.63 (30.39) & $\begin{array}{l}-17.06 \\
(17.3)\end{array}$ & $\begin{array}{l}-12.76 \\
(14.71)\end{array}$ & $\begin{array}{l}3.95 \\
(16.15)\end{array}$ & $\begin{array}{l}16.65 \\
(41.3)\end{array}$ \\
\hline $\begin{array}{l}\text { Pre-monsoon } \\
\text { (Mar-May) }\end{array}$ & 311.37 (43.08) & $\begin{array}{l}-9.86 \\
(21.63)\end{array}$ & $\begin{array}{l}0.07 \\
(15.24)\end{array}$ & $\begin{array}{l}-4.77 \\
(5.1)\end{array}$ & $\begin{array}{l}-12.55 \\
(13.92)\end{array}$ \\
\hline $\begin{array}{l}\text { Monsoon (Jun- } \\
\text { Aug) }\end{array}$ & 99.3 (13.74) & $\begin{array}{l}28.4 \\
(57.59)\end{array}$ & $\begin{array}{l}45.89 \\
(46.58)\end{array}$ & $\begin{array}{l}31.6 \\
(35.7)\end{array}$ & $\begin{array}{l}62.69 \\
(75.26)\end{array}$ \\
\hline $\begin{array}{l}\text { Post-monsoon } \\
\text { (Sep-Nov) }\end{array}$ & $92.48(12.8)$ & $\begin{array}{l}15.39 \\
(9.23)\end{array}$ & $\begin{array}{l}12.64 \\
(18.44)\end{array}$ & $\begin{array}{l}22.02 \\
(22.96)\end{array}$ & $\begin{array}{l}29.47 \\
(53.06)\end{array}$ \\
\hline Annual Average & 722 & $\begin{array}{l}4.22 \\
(26.44)\end{array}$ & $\begin{array}{l}11.46 \\
(23.74)\end{array}$ & $\begin{array}{l}13.2 \\
(19.98)\end{array}$ & $\begin{array}{l}24.07 \\
(45.89)\end{array}$ \\
\hline
\end{tabular}

\subsection{Extreme indices in the basin}

Table 6 presents the values of extreme indices during the reference period (1981-2010), mid-century (2036-2065) and by the end of the century (2071-2100). Here, warm days and the HWDI are projected to increase at an alarming rate; 157 warm days are projected in RCP4.5 and 259 in RCP8.5; however, during the reference period, it is 35 warm days. As for heatwaves, they will occur for 79 days in RCP4.5 and for 176 days in RCP8.5. A detailed assessment and visualization of the extreme indices are presented below. 
Table 6

Extreme indices in the Kabul River Basin during mid-century and by the end of the century. The values in parentheses represent the ensemble standard deviation.

\begin{tabular}{|llllll|}
\hline Indices & $\begin{array}{l}\text { Baseline } \\
\text { Days }\end{array}$ & RCP4.5 & & RCP8.5 & \\
\cline { 6 - 7 } & $\begin{array}{l}\text { (1981- } \\
\text { 2010) }\end{array}$ & $\begin{array}{l}\mathbf{2 0 3 6 - 2 0 6 5} \\
\text { (Mid-century) }\end{array}$ & $\begin{array}{l}\text { 2071-2100 (End } \\
\text { of century) }\end{array}$ & $\begin{array}{l}\text { 2036-2065 } \\
\text { (Mid-century) }\end{array}$ & $\begin{array}{l}\text { 2071-2100 (End } \\
\text { of century) }\end{array}$ \\
\hline CSU & 142 & $161(17)$ & $165(17)$ & $174(15)$ & $199(15)$ \\
\hline CFD & 243 & $211.3(10)$ & $204.8(12)$ & $205.1(10)$ & $177.2(12)$ \\
\hline HWDI & 15 & $59.2(14.3)$ & $79.1(12.4)$ & $83.6(23.2)$ & $176.2(12.4)$ \\
\hline CWDI & 7 & $3.4(2.5)$ & $2.9(2.2)$ & $4.6(2.9)$ & $1.9(2.0)$ \\
\hline TG90P & 35 & $131.8(24.2)$ & $157.2(17.8)$ & $175.2(27.8)$ & $259.0(17.8)$ \\
\hline TN10P & 36 & $11.9(3.5)$ & $11.5(4.0)$ & $11.6(4.0)$ & $5.8(2.5)$ \\
\hline CDD & 54 & $48(12)$ & $47(13)$ & $55(13)$ & $56(14)$ \\
\hline CWD & 9 & $9(3)$ & $10(3)$ & $10(3)$ & $9(3)$ \\
\hline RGT90P & 37 & $35(4.6)$ & $37(5.6)$ & $36(5.1)$ & $35(5.8)$ \\
\hline RLT10P & 278 & $281(7.8)$ & $278(8.5)$ & $281(8.4)$ & $285(9.1)$ \\
\hline
\end{tabular}

\subsubsection{Consecutive Summer Days and Consecutive Frost Days}

Summer days will increase, and the frost days will decrease in the basin. On an average, the summer days (reference period: 142 days) are projected to increase to 199 in RCP8.5 and to 165 days in RCP4.5 by the end of the century. However, frost days would decrease to 177 in the RCP8.5 scenario (reference period: 243.5 days). In Fig. 5, the percent of change from the base period (1981-2010) is shown. The summer days will be more in the north-eastern part and the decrease in the frost days will be more in the south-eastern part of the basin, though similar changes will be observed throughout the basin. The northeastern part of the basin is mostly at a higher altitude, while the south-eastern part is flat-land area, with human settlement. This means that there will be more summer in the upstream area, while the settlement area will have fewer frost days. This will likely influence the livelihood and ecosystem of the region.

\subsubsection{Heatwave Duration Index and Cold Wave Duration Index with respect to the mean of the reference period}

Figure 6 shows the annual values of the HWDI and the CWDI. Here, the projections are of a continuous increase in heatwave and a decrease in cold wave. The HWDI will increase to an average of 79 days in 
RCP4.5 and 176 days in RCP8.5. The CWDI will decrease to 2.9 days in RCP4.5 and 1.9 days in RCP4.5. Thus, there is a higher possibility of uncomfortably hot and unusually humid weather in the future in the KRB.

\subsubsection{Warm days and cold nights with respect to the 90th and 10th percentiles, respectively, of the reference period}

Figure 7 shows that the number of warm days will continually increase, while the number of cold nights will decrease in the future scenario. The average of 35.5 days of warm days will rise to between 157 (RCP4.5) and 259 days (RCP8.5) by the end of the century. However, the average 36.2 days of cold days will decrease between 11.5 (RCP 4.5) and 5.8 days (RCP8.5) by the end of the century. The trend of increasing warm days in RCP8.5 is rather alarming. This increase in diurnal temperature and decrease in nocturnal temperature are likely to have serious impacts on different sectors.

\subsubsection{Consecutive Dry Days and Consecutive Wet Days}

Both CDD and CWD are likely to increase, but not in a distinct pattern. Figure 8 shows that during the reference period (1981 - 2010), the average number of CDD was 54 days; this will change to 47 days in RCP4.5 and to 56 days in RCP8.5 during 2071-2100. Further, while the number of CWD will remain almost the same during the base period, in the future, in both scenarios, it will nominally fluctuate. Spatially, CDD will occur prominently mostly in the west and CWD in the east.

\subsubsection{Very high precipitation and very low precipitation days}

Figure 9 shows that the pattern of extreme precipitation will vary in the future scenario. The 10-year moving average shows that the number of days greater than the 90th percentile is likely to decrease, but with some variability. There is no clear trend, but the end of the century will see an average of 35 wet days, with a standard deviation of six days (reference period: 37 days). In the case of days with very low precipitation, they are likely to increase to 285 (baseline period: 278 days), with a standard deviation of nine days. This change in extreme precipitation patterns is likely to have a great bearing on the quality and quantity of rainfall utilized by human beings and natural resources.

\section{Discussion}

Our study presents the future scenario of precipitation and temperature patterns in the Kabul River Basin. It shows that there will not only be gradual changes in the levels of precipitation and temperature, but there will also be a sharp rise in climatic extremes with pronounced changes in their magnitude and frequency. As communities tend to adapt poorly to climatic extremes, these changes will cause more harm to human health, food security, and the natural ecosystem compared to the gradual changes. Moreover, since the responses of the communities and the natural ecosystem will not be linear and intuitive in response to these extreme events, the impacts they will cause will be much more damaging. In this regard, taking into account the extreme climatic events that are likely to occur in the KRB in the future 
and considering the heterogeneous nature of their impact in terms of time, space, and individual, we discuss below the effects this will have on the four areas of health, agriculture, water resources, and the cryosphere (Table 7). Importantly, these sectors are not stand-alone - they are interlinked; so, any negative influence on them can lead to more stress on the social system in terms of adaptation, while there's also the danger of unhealthy competition to gain access to the resources (Bowles et al., 2014)..

\section{Human health}

The KRB accounts for 35 per cent of Afghanistan's population and has the fastest population growth rate compared to other parts of Afghanistan (MEW and World Bank 2013). The projected increase in heatwaves and summer days in the basin will lead to a surge in illnesses and deaths as the body's ability to regulate its temperature gets compromised. This is likely to have both direct (in the form of escalating vector-borne diseases, illness, and death) and indirect (in the form of pathogenic activities and proliferation of bacteria) impacts on human health (Bowles, Butler, and Friel 2014; McMichael, Haines, Slooff, Sari Kovats, and Organization 1996). Some of the examples are of an increase in waterborne diseases in the United States (Curriero, Patz, Rose, and Lele 2001) and the Pacific Islands (Singh et al. 2001); and rise in deaths in France (Fouillet et al. 2006) and the US (Whitman et al. 1997) due to heatwaves, - more examples in Table 7. Along with climatic factors, non-climatic factors such as demographic distribution, socio-economic status, cultural conditions, adaptive capacity, and access to health care, play a key role (CCSP 2008). Here, it has to be noted that it is the vulnerable section of the population, like women, children, the elderly, and the differently abled people, would be at the higher risk of mortality rate.

\section{Agriculture and food security}

Cereals such as wheat, corn, barley, sorghum, rice, and potatoes, and other entities such as cotton, fruits, nuts, and grapes (Muradi and Boz 2018) are the major agricultural products in the KRB. The projected increase in summer days and heatwaves are bound to influence the cropping system (lizumi and Ramankutty 2015), vegetative growth, fruiting, and grain production across species (Hatfield and Prueger 2015; Mbow et al. 2019). As for precipitation, the primary source of soil moisture, it influences photosynthetic activity (Mavi and Tupper, 2004) and the productivity of crops (Motha 2011), while the optimum temperature range determines the development or wilting of a plant (Backlund, Janetos, and Schimel 2008). Hence, any increase in extreme events will have a direct impact on the agriculture and food security of the basin. Studies in India have shown acceleration of senescence from extreme heat in the wheat (Lobell et al. 2012), and other studies from the United States (Table 7) have provided examples on the risksand uncertainties regarding crop production and food security.

Moreover, it is likely, any adverse impacts on agricultural productivity will have harmful effects on mental health and well-being; they will also lead to conflicts and compel unfair competition for the available natural systems. Then there's the likelihood of increased migration of humans and other species, and invasion by alien species. Nonetheless, the aggregate impacts of climate change and extreme events on 
agricultural productivity are complex to be reliably quantified, mainly due to the difference in climate type and associated agriculture processes and productivity (Gornall et al. 2010).

\section{Water resources and hydrology}

The increase in temperature and decrease in winter and pre-monsoon precipitation in the KRB in the future are likely to influence the availability of water for household use and crop production. Likewise, as consecutive dry days increase and the precipitation days become more inconsistent, there's more likelihood of droughts and floods (Tabari 2020); they will also influence hydropower generation and trigger changes in river flow, sediment load, and even in aquatic biodiversity (Whitehead, Wilby, Battarbee, Kernan, and Wade, 2009). Some examples from Kerala, the Colorado River, and Europe, as shown in Table 7, reflect the influences on the natural cycle of water due to extreme events. Although water is inherently flowing and continually being recharged (Oki and Kanae, 2006), the consistency, availability, and accessibility at a given location and time matter the most. Also, location-specific, efficient water resource management approaches will be affected.

\section{Cryosphere}

The future scenarios indicate that the temperature of the KRB will increase by $2.6^{\circ} \mathrm{C}$ to $5.1^{\circ} \mathrm{C}$ and that the basin will have fewer frost days. This will create additional vulnerability in of the cryosphere. There is likely to be a shift from the solid form of precipitation to the liquid form. The major glaciers in the northwestern part of the basin are likely to decrease significantly. The examples (Table 7) from the Canadian Arctic show that rising temperatures have significantly affected the Arctic ecosystem, while in the Tibet region, glacier retreat has been detected. Similarly, changes in the patterns of ice melt, permafrost, and seasonally frozen ground are likely to affect the entire landscape of the basin, and also detract from its scenic appeal. This will also reduce slope stability, leading to natural hazards like landslide and erosion. Considering the heterogeneous nature of the KRB, only a detailed assessment of the components of the cryosphere and the mass balance in the basin can quantify the exact magnitude of the impacts. 
Table 7

A few examples of the impact of extreme events on the sectors of health, agriculture, water resources, and the cryosphere.

\section{Extreme Examples/Probabilities of Sectoral Impacts/Implications References Events}

\section{Health Sector}

Extreme $\quad \cdot$ Based on 548 reported outbreaks of waterborne diseases

precipitation from 1948 to 1994 . Precipitation above the 90 th percentile was followed by 51 per cent outbreak of waterborne

(Curriero et al. 2001) diseases.

United States

- 68 per cent of the waterborne diseases occurred after the 80th percentile of the precipitation event. $\begin{array}{ll}\text { Extreme } & \text { D During the most intense heat of July } 1995, \text { there occured } \\ \text { temperature } & 514 \text { heat-related deaths ( } 12 \text { per } 100,000 \text { population). This } \\ & \text { is a } 31 \text { per cent increase above the baseline. }\end{array}$

Extreme $\quad$ Casualties took place even in tropical countries where temperature people are more acclimatized to the hot climate.

and precipitation

Extreme $\quad$ Excess deaths of nearly 14,947 people in France in temperature August 2003 had to do with heatwaves.

\section{Extreme - During the summer of 2003 in Europe, there occurred temperature 70,000 additional deaths. This data was culled from 16 European countries.}

\section{Extreme} temperature precipitation
- There was a statistically significant relationship between extreme temperature and diarrhoea cases from 1986 to 1994.
(Whitman et al. 1997)

Chicago, United States

(McMichael et al. 2008), United States
(Fouillet et al. 2006; Poumadere, Mays, Le Mer, and Blong 2005), France

(Robine et al. 2008)

European countries

(Singh et al. 2001) Pacific Islands

- Extreme rainfall was associated with statistically significant increase in diarrhoea cases in the same month, while the cases decreased in the following month.

Extreme $\quad$ Occurrence of heatstroke and dehydration, as well as temperature
(Seneviratne et al., 2012), based on global data

\section{Agriculture Sector}

Extreme $\quad$ There was damage to the tune of nearly 1 billion US temperature dollars due to weather-related disasters.

and precipitation

- The socio-economic costs of these extreme events are

(Motha 2011)

United States far-reaching and long-lasting.

Extreme heat $\quad$ Nine years of satellite measurement of crop response to temperatures greater than $34^{\circ} \mathrm{C}$ in northern India showed a negative impact on wheat growth and yield.

(Lobell, Sibley, and Ortiz-Monasterio 2012) India 


\section{Extreme Examples/Probabilities of Sectoral Impacts/Implications References}

Extreme $\quad$ There occurred 20-49 per cent variance in yield temperature anomalies due to extreme climate events, which were and largely attributed to temperature-related extremes.

precipitation

- The regions that are particularly susceptible are North America (in the case of maize, spring wheat, and soy production) and Asia (in the case of maize and rice production).

Extreme $\quad$ Adverse effects on pollination in the case of crops like temperature

\section{Extreme} precipitation and increase in GHG emissions

Zea mays L. and Brassica oleracea L.

- A shift in the agricultural production zones around the nation.

- Significant negative pressure on maize yields, farm production levels, and farmers.
(Vogel et al. 2019)

\section{Water Resources and Hydrology}

Extreme $\quad$ Extreme rainfall events increased the intensity and precipitation frequency of surface flow.

- The base flow was not largely impacted.

- Multi-year drought might increase and be more intense.

Extreme $\quad .66$ years of climatic analyses show droughts in Kerala, precipitation

Variability in precipitation and temperature patterns

\section{Extreme} temperature and variability in precipitation events India, but there was a flood in 2018.

- The average storage, seasonal distribution in the inflow, and the hydropower produced got influenced.
(Samuels, Rimmer, \& Alpert, 2009) Jordan River
(Hatfield and Prueger 2015), lowa, United States

(Rosenzweig, 2000; Rosenzweig, Tubiello, Goldberg, Mills, and Bloomfield 2002), United States

\section{Cryosphere}

\section{Extreme temperature}

- Extreme warming during the summer of 2008 showed the deepening of the permafrost active layer; loss of the iceshelf area, perennial lake ice, and sea ice; loss of icedammed freshwater lakes; and the loss of the cryoecosystem.
(Vincent et al. 2009), Ward Hunt Island and its vicinity in the Canadian Arctic 


\begin{tabular}{|lll|}
\hline $\begin{array}{l}\text { Extreme } \\
\text { Events }\end{array}$ & Examples/Probabilities of Sectoral Impacts/Implications & References \\
\hline $\begin{array}{l}\text { Extreme } \\
\text { temperature }\end{array}$ & $\begin{array}{l}\text { - Snow-dominated watersheds will shift towards rain- } \\
\text { dominated ones, resulting in high flows, especially during } \\
\text { late autumn and winter rather than spring, and lower flows } \\
\text { in summer. }\end{array}$ & $\begin{array}{l}\text { (Clifton et al. 2018), } \\
\text { Blue Mountains, } \\
\text { Oregon, United States }\end{array}$ \\
$\begin{array}{l}\text { Extreme } \\
\text { temperature } \\
\text { and } \\
\text { precipitation }\end{array}$ & $\begin{array}{l}\text { - Glacier retreat. } \\
\text { - Inconsistent changes in snow cover. }\end{array}$ & $\begin{array}{l}\text { (Kang et al. 2010), } \\
\text { Tibetan Plateau }\end{array}$ \\
\hline
\end{tabular}

Further, apart from these four sectors, the altered frequencies and amplitude of extreme events may change the demographic rates, fitness, and the community structure of species (Ma, Rudolf and $\mathrm{Ma}$ 2015); they will also have a bearing on wind-power generation due to changes in the intensity and duration of wind speed. There is also the probability of an increase in disasters and adverse changes in the aquatic ecosystem; meanwhile, the availability of timber and non-timber forest products, too, will be under threat This list of implications in the different sectors can be extensive but along with the relative value of change in any hydro-meteorological characteristics of a location; the spatial extent, location's climatology, the adaptive capacity of the human and natural system also plays a crucial role in determining the impact of the change in that location (Meehl et al., 2000).

\section{Conclusion}

This study has analysed the future climate change scenarios and extreme events in the Kabul River Basin by downscaling the four global climate model runs for RCP4.5 and 8.5. The models were selected by considering the changes in extremes and because of their skill to represent the historical climate cycle. The selected global climate models suggest an increase in the average temperature (by $2.6-5.1^{\circ} \mathrm{C}$ ) and precipitation (by 4.5-12.2 per cent) levels in the KRB by the end of the century. However, the seasonal analysis shows that the precipitation level during the pre-monsoon season (which accounts for 43 per cent of the total precipitation) is likely to decrease by the end of the century. Likewise, winter precipitation will decrease (by $-13 \mathrm{~mm} /$ year with a standard deviation of 14) in RCP4.5; while it will increase (by 16 $\mathrm{mm} /$ year with a standard deviation of 41.3 ) in RCP8.5. This variability in precipitation in the basin is accompanied by increasing temperatures in both scenarios, thereby escalating the state of climatic vulnerability.

Further, the analysis of the extreme events in the basin brought forth some noteworthy points: warm days, consecutive summer days, consecutive dry days, and the duration of heatwaves will increase; at the same time, the number of cold nights, consecutive frost days, and the duration of cold waves will decrease. The discussion section has highlighted the impacts of these extreme events on the sectors of health, agriculture, water resources, and the cryosphere. And these impacts are likely to threaten human health and well-being in diverse ways. As for extreme precipitation events, they can exacerbate water-related 
disasters like floods and flash floods. Similarly, agricultural productivity stands to be affected by the decrease in frost days and the increase in warm days. These changes can affect the overall ecosystem of the basin.

In a nutshell, this study presents a glimpse of how human health, agriculture, water, and the cryosphere can be adversely affected by extreme events. It also outlines the environmental challenges to the basin, which should compel urgent actions simultaneously on many fronts so that the basin is in a position to sustain itself. The detailed assessment of the hydro-climatic variables and their impact on different sectors would help in being better prepared for any climatic eventuality in the future. It has also got to be emphasized that there's a need for a robust and actionable climate information system at the sub-basin and regional levels and also an urgency for policy responses to climate change adaptation.

\section{Declarations}

\section{Conflicts of interest/Competing interests:}

There is no conflict of interest among the authors.

\section{Availability of data and material:}

The global data were downloaded from the climate4impact.eu portal and downscaled data can be shared on request to the corresponding author

\section{Code availability}

The codes for sectorial analysis can be shared on request to the corresponding author

\section{Authors contributions:}

Kabi Raj Khatiwada conceptualized, designed and lead the overall analysis of the manuscript. Saurav Pradhanaga and Santosh Nepal helped in the methodology, analysis, interpretation, visualization of the results, and finalizing the manuscript

\section{Funding}

Not applicable

\section{Acknowledgement:}

This study was supported by the Strengthening Water Resources in Afghanistan (SWaRMA) Initiative of ICIMOD, which is supported by the Governments of Afghanistan and Australia. This study was supported by core funds of ICIMOD contributed by the Governments of Afghanistan, Australia, Austria, Bangladesh, Bhutan, China, India, Myanmar, Nepal, Norway, Pakistan, and Switzerland. 


\section{References}

1. Backlund P, Janetos A, Schimel D (2008) The effects of climate change on agriculture, land resources, water resources, and biodiversity in the United States. Synthesis and Assessment Product 4.3. Washington, DC: US Environmental Protection Agency, Climate Change Science Program. 240 P.

2. Bader DC, Covey C, Gutowski Jr WJ, Held IM, Miller RL, Tokmakian RT, Zhang MH (2008) Climate models: an assessment of strengths and limitations

3. Barnett TP, Adam JC, Lettenmaier DP (2005) Potential impacts of a warming climate on water availability in snow-dominated regions. Nature, 438, 303. Retrieved from http://dx.doi.org/10.1038/nature04141

4. Boberg F, Christensen JH (2012) Overestimation of Mediterranean summer temperature projections due to model deficiencies. Nature Climate Change 2(6):433-436

5. Bokhari SAA, Ahmad B, Ali J, Ahmad S, Mushtaq H, Rasul G (2018) Future climate change projections of the Kabul River Basin using a multi-model ensemble of high-resolution statistically downscaled data. Earth Systems Environment 2(3):477-497

6. Bolch T, Kulkarni A, Kääb A, Huggel C, Paul F, Cogley JG, ... Stoffel M (2012) The state and fate of himalayan glaciers. Science, 310-314. https://doi.org/10.1126/science.1215828

7. Bowles DC, Butler CD, Friel S (2014) Climate change and health in Earth's future. Earth's Future 2(2):60-67

8. Cann KF, Thomas DR, Salmon RL, Wyn-Jones AP, Kay D (2013) Extreme water-related weather events and waterborne disease. Epidemiology Infection 141(4):671-686

9. CCSP (2008) Analyses of the effects of global change on human health and welfare and human systems

10. Christensen NS, Wood AW, Voisin N, Lettenmaier DP, Palmer RN (2004) The effects of climate change on the hydrology and water resources of the Colorado River basin. Clim Change 62(1-3):337-363

11. Clifton CF, Day KT, Luce CH, Grant GE, Safeeq M, Halofsky JE, Staab BP (2018) Effects of climate change on hydrology and water resources in the Blue Mountains, Oregon, USA. Climate Services, 10, 9-19

12. Curriero FC, Patz JA, Rose JB, Lele S (2001) The association between extreme precipitation and waterborne disease outbreaks in the United States, 1948-1994. Am J Public Health 91(8):11941199

13. Easterling DR, Evans JL, Groisman PY, Karl TR, Kunkel KE, Ambenje P (2000) Observed variability and trends in extreme climate events: a brief review. Bull Am Meteor Soc 81(3):417-426

14. Easterling DR, MeehI GA, Parmesan C, Changnon SA, Karl TR, Mearns LO (2000) Climate extremes: observations, modeling, and impacts. Science 289(5487):2068-2074

15. Epstein PR (1999) Climate and health. Science 285(5426):347-348

16. Fouillet A, Rey G, Laurent F, Pavillon G, Bellec S, Guihenneuc-Jouyaux C, ... Hémon D (2006) Excess mortality related to the August 2003 heat wave in France. Int Arch Occup Environ Health 80(1):16-24 
17. Ghulami M (2017) Assessment of climate change impacts on water resources and agriculture in data-scarce Kabul basin, Afghanistan

18. Gornall J, Betts R, Burke E, Clark R, Camp J, Willett K, Wiltshire A (2010) Implications of climate change for agricultural productivity in the early twenty-first century. Philosophical Transactions of the Royal Society B: Biological Sciences 365(1554):2973-2989

19. Hashmi R, Masood A, Mushtaq H, Bukhari SAA, Ahmad B, Tahir AA (2020) Exploring climate change impacts during the first half of the 21st century on flow regime of the transboundary Kabul River in the Hindukush region. Journal of Water Climate Change 11(4):1521-1538

20. Hassanyar MH, Hassani S, Dozier J (2017) Ensemble GCMs Climate Change Projections for Kabul River Basin, Afghanistan under Representative Concentration Pathways. GRD Journals-Global Research and Development Journalfor Engineering, 2(5)

21. Hatfield JL, Prueger JH (2015) Temperature extremes: Effect on plant growth and development. Weather Climate Extremes 10:4-10

22. Hirabayashi Y, Mahendran R, Koirala S, Konoshima L, Yamazaki D, Watanabe S, ... Kanae S (2013) Global flood risk under climate change. Nature Climate Change 3(9):816-821

23. Huss M, Hock R (2018) Global-scale hydrological response to future glacier mass loss. Nature Climate Change 8(2):135-140. https://doi.org/10.1038/s41558-017-0049-x

24. lizumi T, Ramankutty N (2015) How do weather and climate influence cropping area and intensity? Global Food Security 4:46-50

25. Immerzeel WW, Lutz AF, Andrade M, Bahl A, Biemans H, Bolch T, ... Elmore AC (2020) Importance and vulnerability of the world's water towers. Nature 577(7790):364-369

26. IPCC (2014a) Climate change 2014: impacts, adaptation, and vulnerability-Part B: regional aspectsContribution of Working Group II to the Fifth Assessment Report of the Intergovernmental Panel on Climate Change (Barros VR, Field CB, Dokke DJ, Mastrandrea MD, Mach KJ, Bilir TE, ... Genova RC (eds)). Cambridge University Press

27. IPCC (2014b) Climate Change 2014: Impacts, Adaptation, and Vulnerability. Part B: Regional Aspects. Contribution of Working Group II to the Fifth Assessment Report of the Intergovernmental Panel on Climate Change [Barros, V.R., C.B. Field, Dokken DJ, M.D. Mastrandre. Cambridge, United Kingdom and New York, NY, USA: Cambridge University Press

28. Kaini S, Nepal S, Pradhananga S, Gardner T, Sharma AK (2019) Representative general circulation models selection and downscaling of climate data for the transboundary Koshi river basin in China and Nepal. International Journal of Climatology

29. Kang S, Xu Y, You Q, Flügel W-A, Pepin N, Yao T (2010) Review of climate and cryospheric change in the Tibetan Plateau. Environmental Research Letters 5(1):15101

30. Karl TR, Easterling DR (1999) Climate extremes: selected review and future research directions. Clim Change 42(1):309-325

31. Krishnan R, Shrestha AB, Ren G, Rajbhandari R, Saeed S, Sanjay J, ... You Q (2019) Unravelling climate change in the Hindu Kush Himalaya: rapid warming in the mountains and increasing 
extremes. In: The Hindu Kush Himalaya Assessment. Springer, pp 57-97

32. Kumaresan J, Sathiakumar N (2010) Climate change and its potential impact on health: a call for integrated action. SciELO Public Health

33. Laghari AN, Vanham D, Rauch W (2012) The Indus basin in the framework of current and future water resources management. Hydrol Earth Syst Sci 16(4):1063

34. Lashkaripour GR, Hussaini SA (2008) Water resource management in Kabul river basin, eastern Afghanistan. Environmentalist 28(3):253-260

35. Lehner B, Döll P, Alcamo J, Henrichs T, Kaspar F (2006) Estimating the Impact of Global Change on Flood and Drought Risks in Europe: A Continental, Integrated Analysis. Clim Change 75(3):273-299

36. Lobell DB, Sibley A, Ortiz-Monasterio JI (2012) Extreme heat effects on wheat senescence in India. Nature Climate Change 2(3):186-189

37. Lutz AF, Immerzeel WW, Shrestha AB, Bierkens MFP (2014) Consistent increase in High Asia's runoff due to increasing glacier melt and precipitation. Nature Climate Change 4(7):587

38. Lutz AF, ter Maat HW, Biemans H, Shrestha AB, Wester P, Immerzeel WW (2016) Selecting representative climate models for climate change impact studies: an advanced envelope-based selection approach. Int J Climatol 36(12):3988-4005

39. Ma G, Rudolf VHW, Ma C (2015) Extreme temperature events alter demographic rates, relative fitness, and community structure. Glob Change Biol 21(5):1794-1808

40. Mack TJ, Akbari M, Ashoor Mh, Chornack MP, Coplen TB, Emerson DG, ... Plummer, Ln (2010) Conceptual model of water resources in the Kabul Basin, Afghanistan

41. Mack TJ, Chornack MP, Coplen TB, Plummer LN, Rezai MT, Verstraeten IM (2010) Availability of water in the Kabul Basin, Afghanistan. US Geological Survey

42. Mavi HS, Tupper GJ (2004) Agrometeorology: principles and applications of climate studies in agriculture. CRC Press

43. Mbow C, Rosenzweig C, Barioni LG, Benton TG, Herrero M, Krishnapillai M, ... Sapkota TB (2019) Food security. In: Climate Change and Land: an IPCC special report on climate change, desertification, land degradation, sustainable land management, food security and greenhouse gas fluxes in terrestrial ecosystems. IPCC

44. McMichael AJ, Haines JA, Slooff R, Kovats S, R., \& Organization WH (1996) Climate change and human health: an assessment. World Health Organization

45. McMichael AJ, Wilkinson P, Kovats RS, Pattenden S, Hajat S, Armstrong B, ... Kingkeow C (2008) International study of temperature, heat and urban mortality: the 'ISOTHURM'project. Int $\mathrm{J}$ Epidemiol 37(5):1121-1131

46. Meehl GA, Karl T, Easterling DR, Changnon S, Pielke R Jr, Changnon D, ... Kunkel KE (2000) An introduction to trends in extreme weather and climate events: observations, socioeconomic impacts, terrestrial ecological impacts, and model projections. Bull Am Meteor Soc 81(3):413-416 
47. Meresa HK, Romanowicz RJ, Napiorkowski JJ (2017) Understanding changes and trends in projected hydroclimatic indices in selected Norwegian and Polish catchments. Acta Geophys 65(4):829-848

48. MeW (2019) Report on Kabul River Basin water balance modelling using JAMS/J2000 application

49. MEW, \& World Bank (2013) Investment Plan for Kabul River Basin. Retrieved from https://afghanwaters.net/wp-content/uploads/2017/10/2013-KRB-Investment-Plan.pdf

50. Mishra V, Shah HL (2018) Hydroclimatological perspective of the Kerala flood of 2018. J Geol Soc India 92(5):645-650

51. MoFE (2019) Climate change scenarios for Nepal for National Adaptation Plan (NAP). Ministry of Forests and Environment Kathmandu

52. Motha RP (2011) The impact of extreme weather events on agriculture in the United States. In: Challenges and opportunities in agrometeorology. Springer, $\mathrm{pp}$ 397-407

53. Muradi AJ, Boz I (2018) The contribution of agriculture sector in the economy of Afghanistan. International Journal of Scientific Research and Management, 6(10)

54. Murray V, Ebi K (2012) IPCC special report on managing the risks of extreme events and disasters to advance climate change adaptation (SREX). Retrieved from https://jech.bmj.com/content/66/9/759.short

55. Najmuddin O, Deng X, Siqi J (2017) Scenario analysis of land use change in Kabul river basin-a river basin with rapid socio-economic changes in Afghanistan. Physics Chemistry of the Earth Parts a/B/C 101:121-136

56. Nelson GC, Rosegrant MW, Koo J, Robertson R, Sulser T, Zhu T, ... Batka M (2009) Climate change: Impact on agriculture and costs of adaptation, vol 21. Intl Food Policy Res Inst

57. NEPA, \& UNEP (2015) Climate Change and Governance in Afghanistan. Kabull: National Environmental Protection Agency and United Nations Environment Programme

58. Oki T, Kanae S (2006) Global hydrological cycles and world water resources. Science 313(5790):1068-1072

59. Palazzi E, Von Hardenberg J, Provenzale A (2013) Precipitation in the Hindu-Kush Karakoram Himalaya: observations and future scenarios. Journal of Geophysical Research: Atmospheres 118(1):85-100

60. Parmesan C, Root TL, Willig MR (2000) Impacts of extreme weather and climate on terrestrial biota. Bull Am Meteor Soc 81(3):443-450

61. Poumadere M, Mays C, Le Mer S, Blong R (2005) The 2003 heat wave in France: dangerous climate change here and now. Risk Analysis: An International Journal 25(6):1483-1494

62. Robine J-M, Cheung SLK, Le Roy S, Van Oyen H, Griffiths C, Michel J-P, Herrmann FR (2008) Death toll exceeded 70,000 in Europe during the summer of 2003. CR Biol 331(2):171-178

63. Rosenzweig C (2000) Climate change and agriculture. NABC 
64. Rosenzweig C, Iglesius A, Yang X-B, Epstein PR, Chivian E (2001) Climate change and extreme weather events-Implications for food production, plant diseases, and pests

65. Rosenzweig C, Tubiello FN, Goldberg R, Mills E, Bloomfield J (2002) Increased crop damage in the US from excess precipitation under climate change. Glob Environ Change 12(3):197-202

66. Samuels R, Rimmer A, Alpert P (2009) Effect of extreme rainfall events on the water resources of the Jordan River. J Hydrol 375(3):513-523

67. Savage M, Dougherty B, Hamza M, Butterfield R, Bharwani S (2009) Socio-economic impacts of climate change in Afghanistan. Stockholm Environment Institute: Oxford, UK

68. Seneviratne SI, Nicholls N, Easterling D, Goodess CM, Kanae S, Kossin J, ... Zwiers FW (2012) Changes in climate extremes and their impacts on the natural physical environment. In Managing the Risks of Extreme Events and Disasters to Advance Climate Change Adaptation: Special Report of the Intergovernmental Panel on Climate Change (pp. 109-230). https://doi.org/10.1017/СB09781139177245.006

69. Shen Y, Oki T, Kanae S, Hanasaki N, Utsumi N, Kiguchi M (2014) Projection of future world water resources under SRES scenarios: an integrated assessment. Hydrol Sci J 59(10):1775-1793

70. Shroder JF, Ahmadzai SJ (2016) Transboundary water resources in Afghanistan: Climate change and land-use implications. Elsevier

71. Siddiqui T, Bhagat RB, Banerjee S, Liu C, Sijapati B, Memon R, ... Arif GM (2019) Migration in the Hindu Kush Himalaya: Drivers, Consequences, and Governance. In: The Hindu Kush Himalaya Assessment. Springer, pp 517-544

72. Sidiqi M, Shrestha S, Ninsawat S (2018) Projection of climate change scenarios in the Kabul River Basin, Afghanistan. CURRENT SCIENCE 114(6):1304

73. Singh RB, Hales S, De Wet N, Raj R, Hearnden M, Weinstein P (2001) The influence of climate variation and change on diarrheal disease in the Pacific Islands. Environ Health Perspect 109(2):155-159

74. Tabari H (2020) Climate change impact on flood and extreme precipitation increases with water availability. Sci Rep 10(1):1-10

75. Tünnermeier T, Houben G, Himmelsbach T (2005) Hydrogeology of the Kabul Basin, part i: geology, aquifer characteristics, climate and hydrography. BGR Record, (10277/05)

76. Van Vuuren DP, Edmonds J, Kainuma M, Riahi K, Thomson A, Hibbard K, ... Lamarque J-F (2011) The representative concentration pathways: an overview. Climatic Change, 109(1-2), 5

77. Vincent WF, Whyte LG, Lovejoy C, Greer CW, Laurion I, Suttle CA, ... Mueller DR (2009) Arctic microbial ecosystems and impacts of extreme warming during the International Polar Year. Polar Sci 3(3):171180

78. Vogel E, Donat MG, Alexander LV, Meinshausen M, Ray DK, Karoly D, ... Frieler K (2019) The effects of climate extremes on global agricultural yields. Environmental Research Letters 14(5):54010 
79. Vörösmarty CJ, Green P, Salisbury J, Lammers RB (2000) Global Water Resources: Vulnerability from Climate Change and Population Growth. Science, 289(5477), 284 LP - 288. https://doi.org/10.1126/science.289.5477.284

80. Wester P, Mishra A, Mukherji A, Shrestha AB (2019) The Hindu Kush Himalaya assessment: mountains, climate change, sustainability and people. Springer Nature

81. Whitehead PG, Wilby RL, Battarbee RW, Kernan M, Wade AJ (2009) A review of the potential impacts of climate change on surface water quality. Hydrol Sci J 54(1):101-123

82. Whitman S, Good G, Donoghue ER, Benbow N, Shou W, Mou S (1997) Mortality in Chicago attributed to the July 1995 heat wave. Am J Public Health 87(9):1515-1518

83. Wi S, Yang YCE, Steinschneider S, Khalil A, Brown CM (2015) Calibration approaches for distributed hydrologic models in poorly gaged basins: implication for streamflow projections under climate change. Hydrol Earth Syst Sci 19(2):857-876

84. Wu X, Lu Y, Zhou S, Chen L, Xu B (2016) Impact of climate change on human infectious diseases: Empirical evidence and human adaptation. Environ Int 86:14-23

\section{Figures}

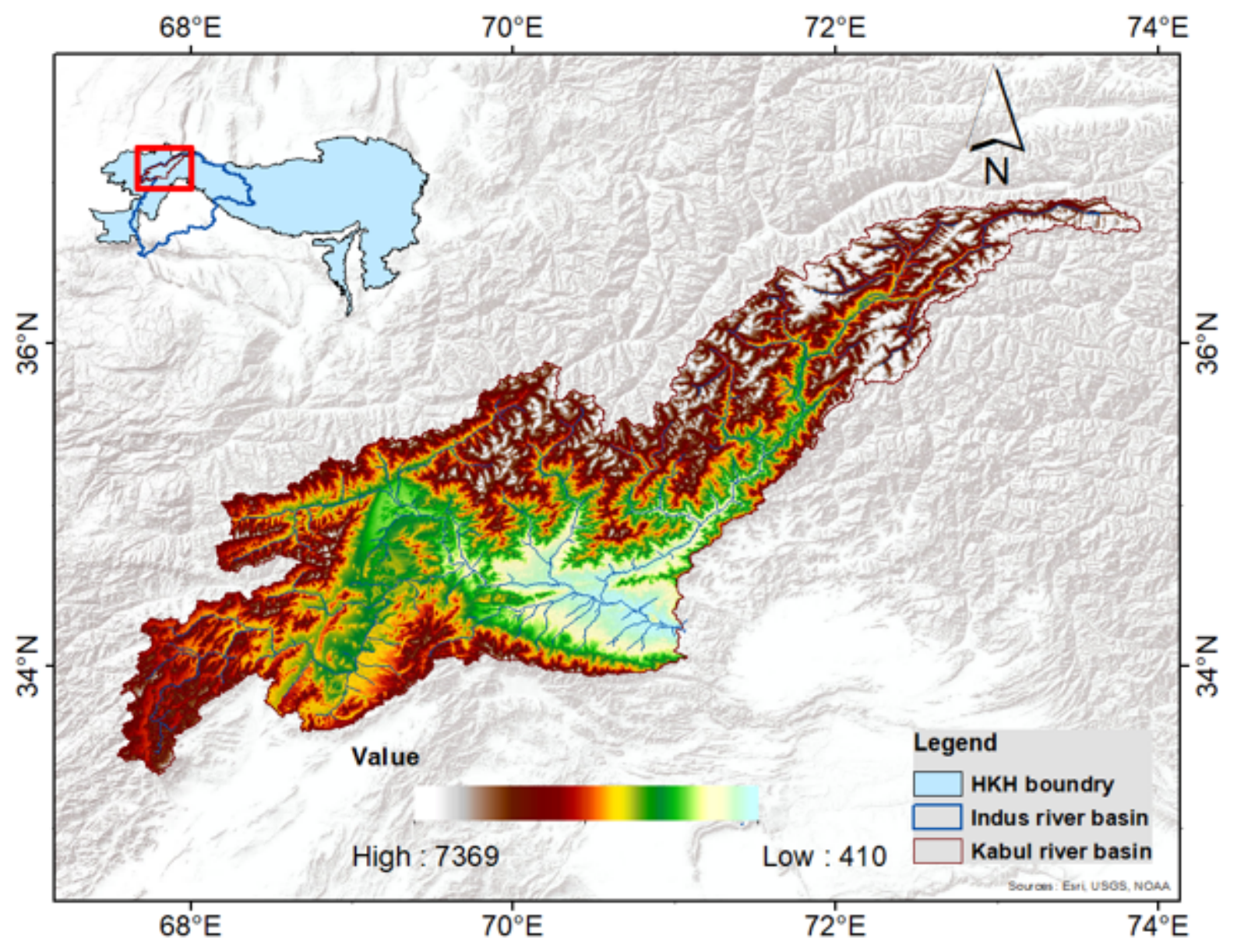

Figure 1 
The Kabul River Basin (centre of the figure), the Hindu Kush Himalaya (the area with a blue shade and black boundary at the north-west corner of the figure)and the Indus River Basin (the area with a blue boundary at the north-west corner of the figure).

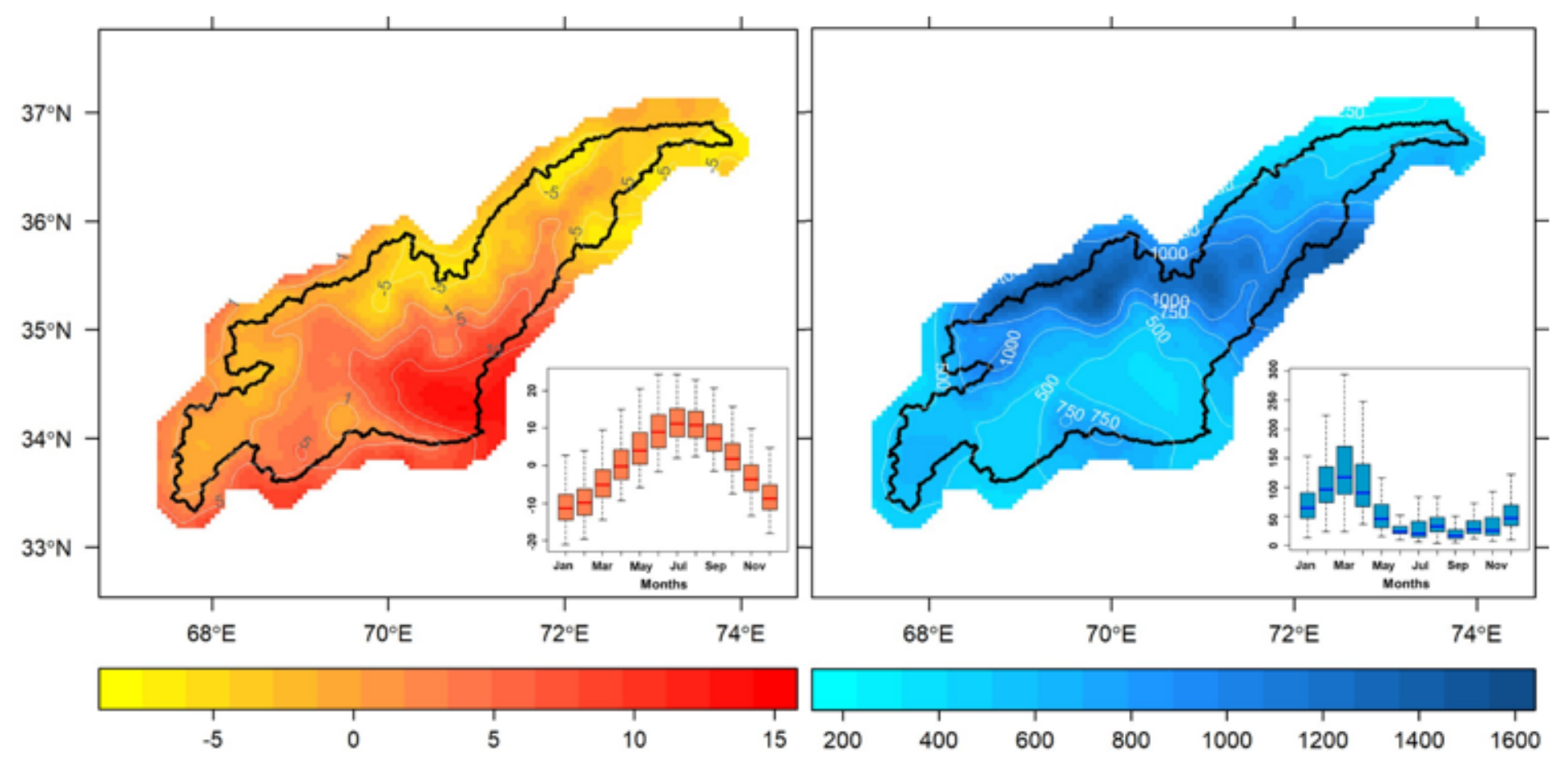

Figure 2

Spatial variations in precipitation and temperature (left) and precipitation (right) in the Kabul River Basin. And in the south-east corner of the figure, the temporal (monthly) value is shown. 


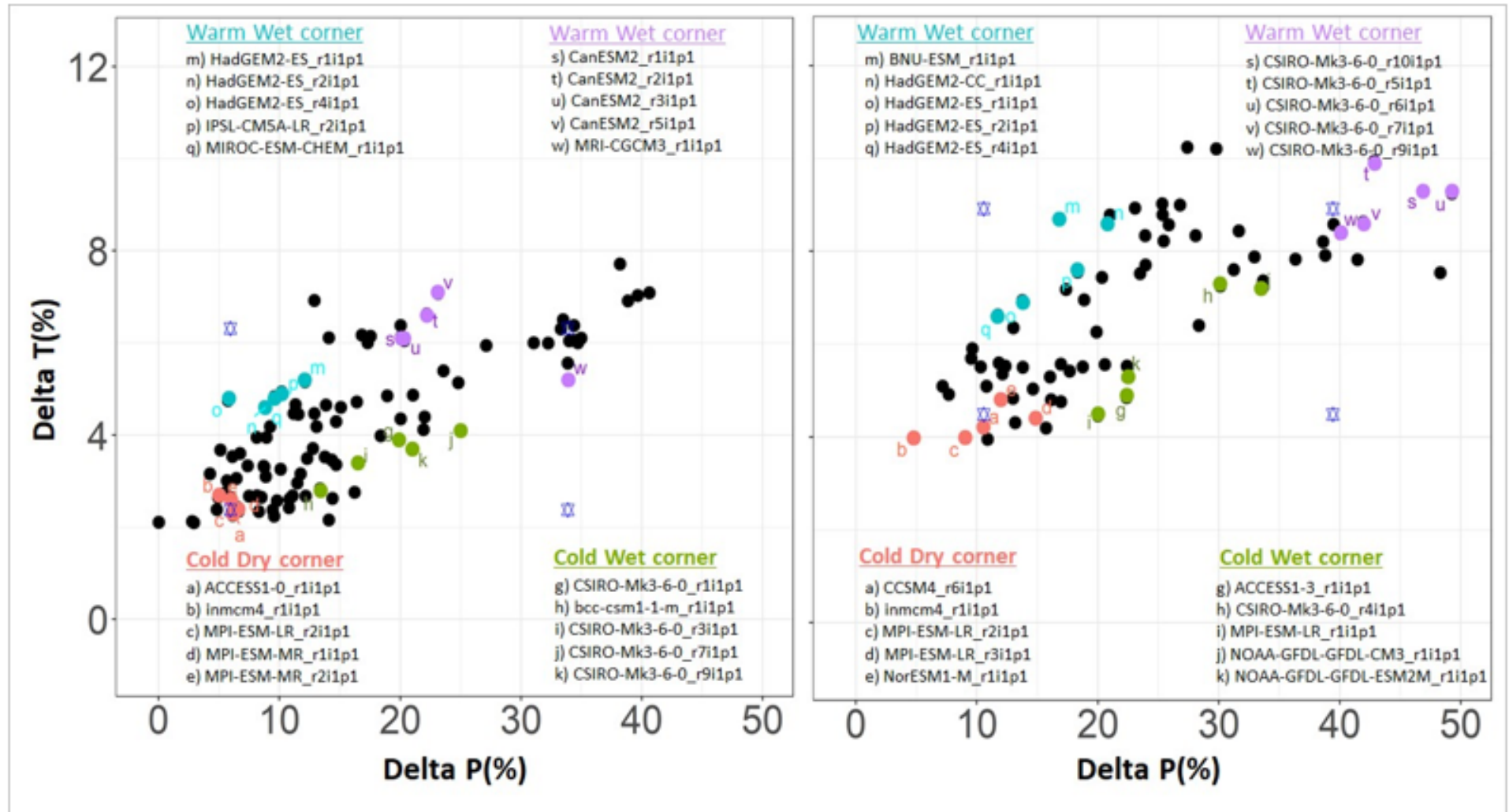

Figure 3

Delta P and Delta T changes between 1981-2010 and 2017-2100 in RCP4.5 (left) and RCP8.5 (right) scenarios. 


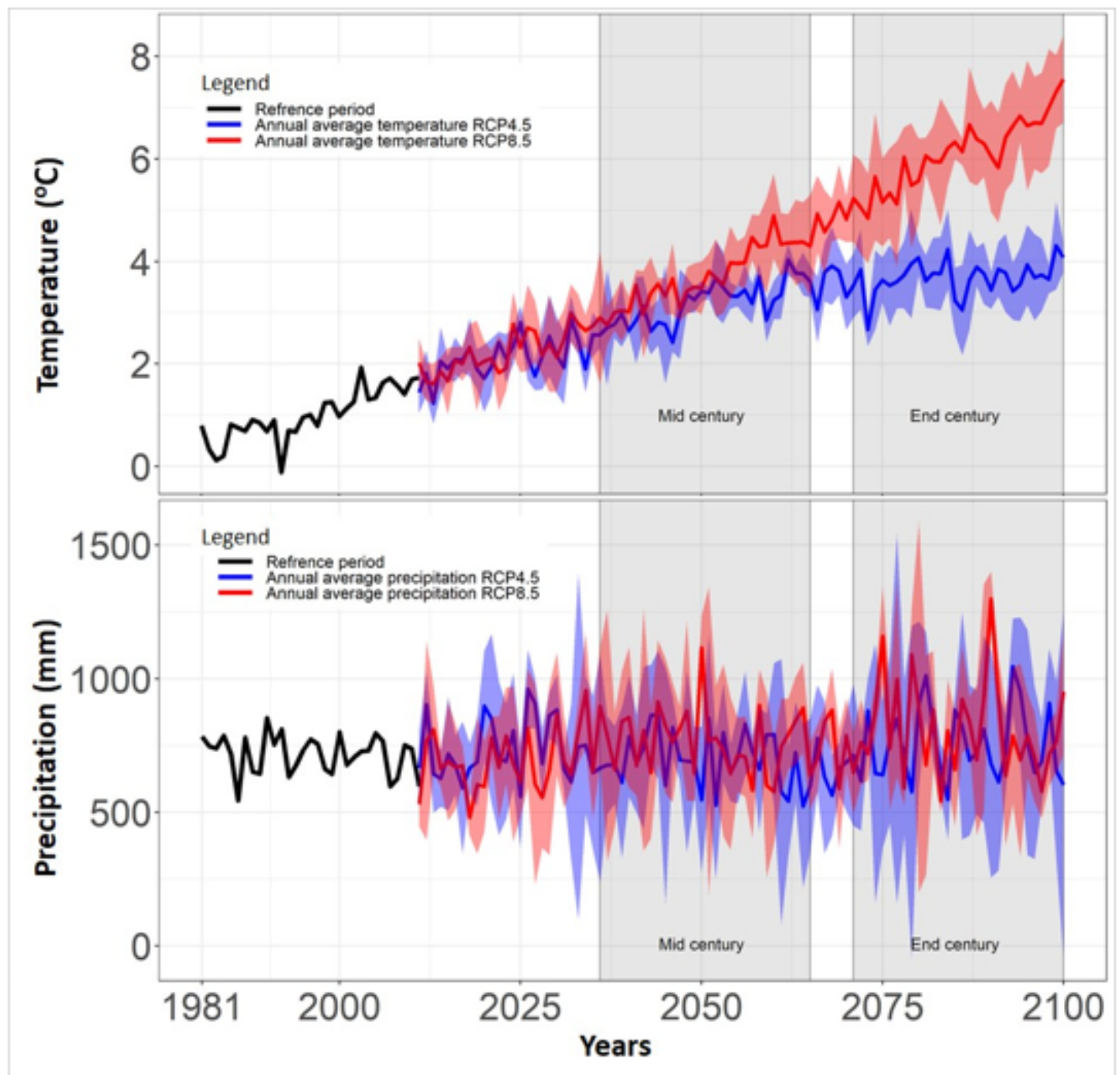

Figure 4

Temperature and precipitation levels in future scenarios. 


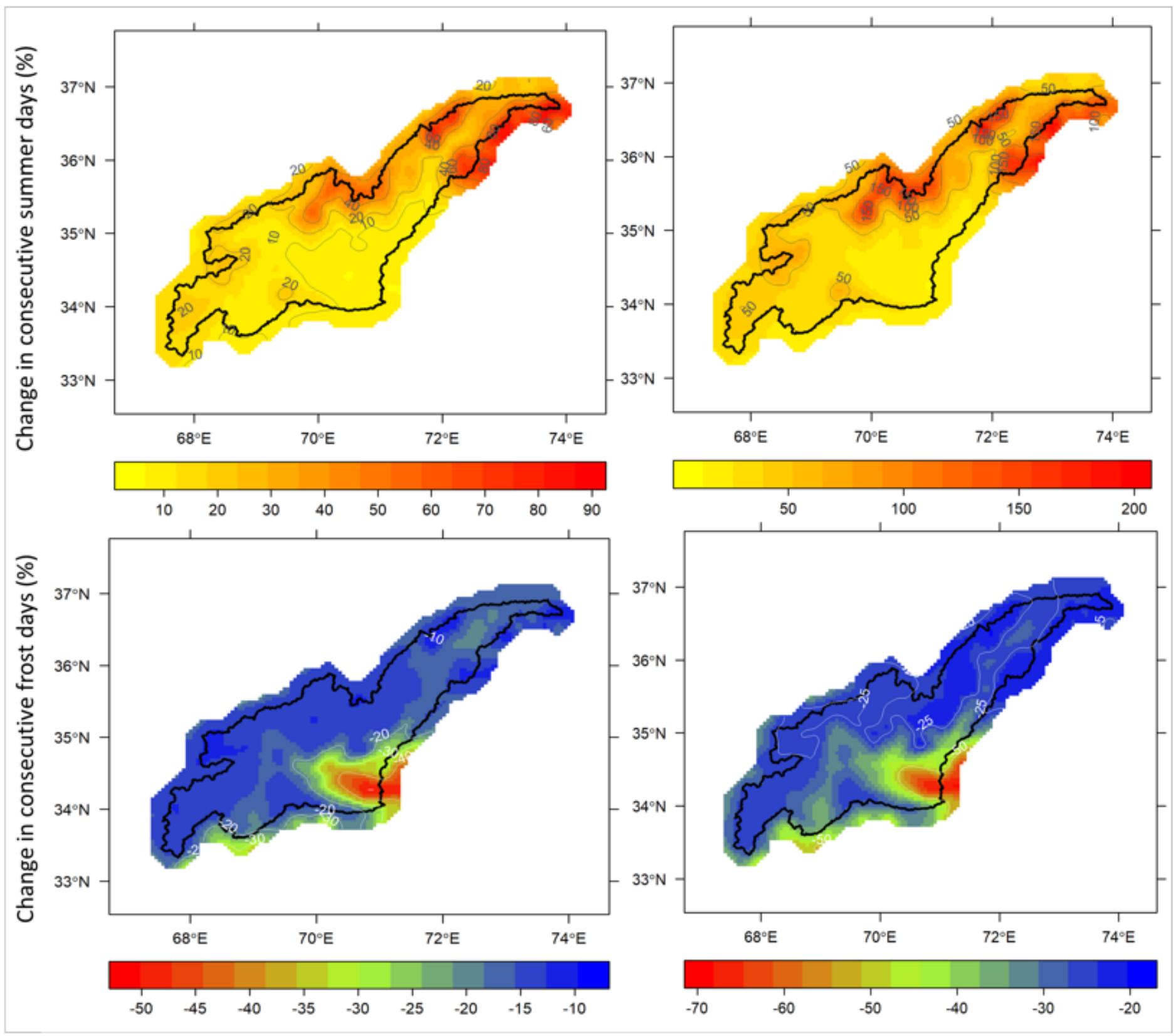

Figure 5

The percentage of the change in consecutive summer days (top) and winter days (bottom) during 20712100 in two RCP scenarios, with the baseline period (1981-2010). 


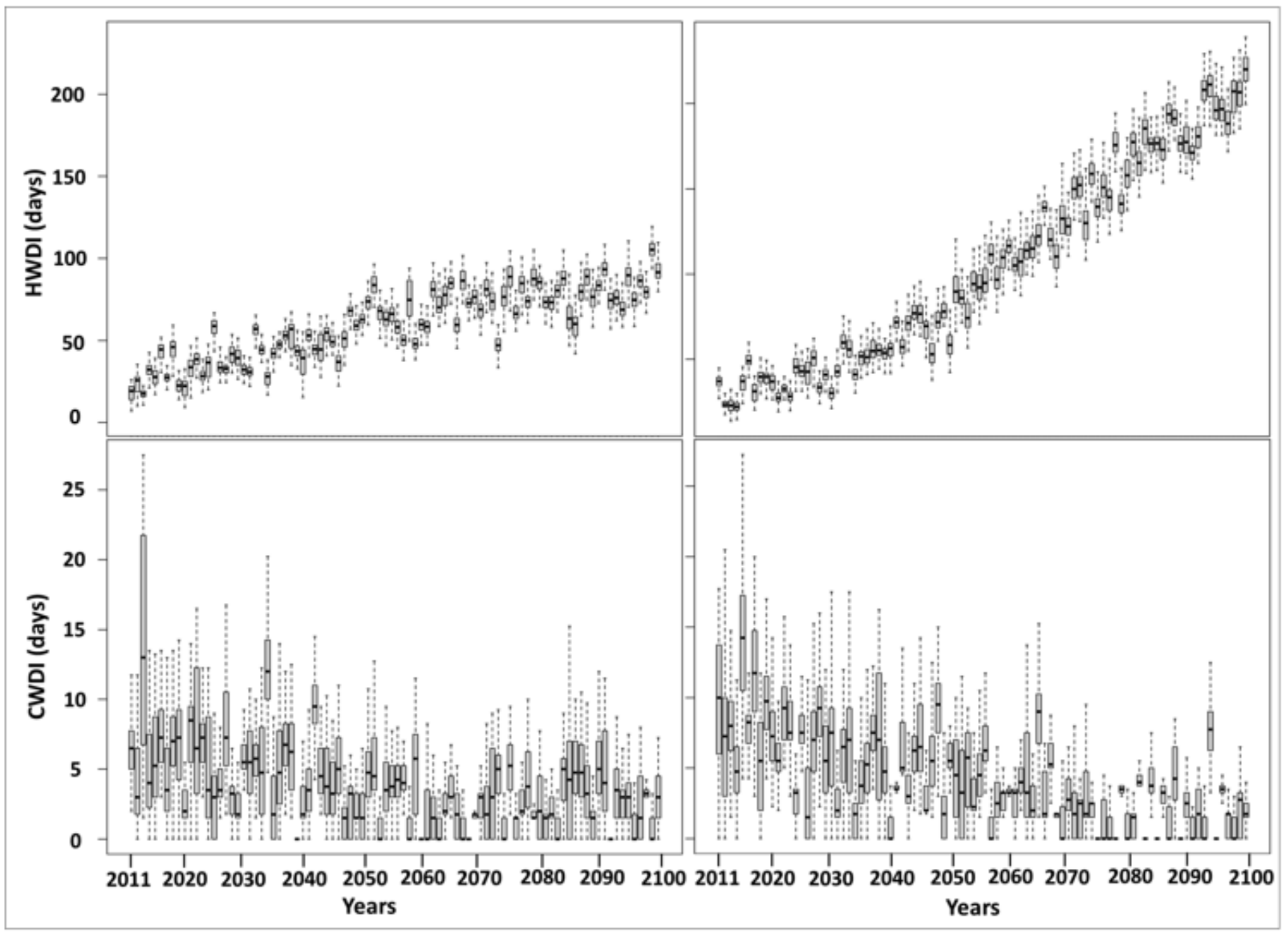

Figure 6

The annual averages of heatwave (upper panel) and cold wave (lower panel) in the Kabul River Basin in two RCP scenarios. 


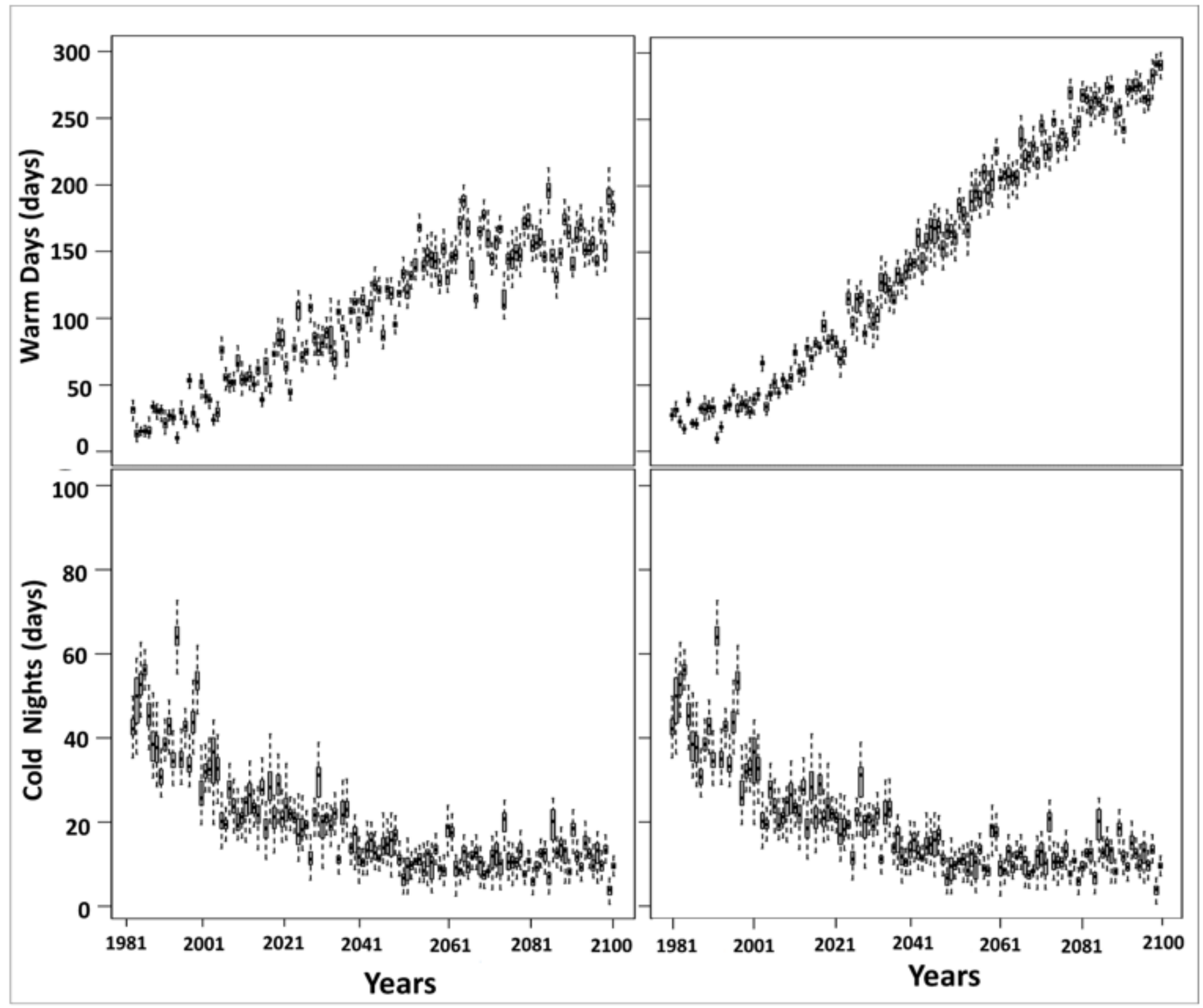

Figure 7

The average annual warm days (upper panel) and cold nights (lower panel) in two different scenarios, from 1981 to 2100, in the Kabul River Basin. 

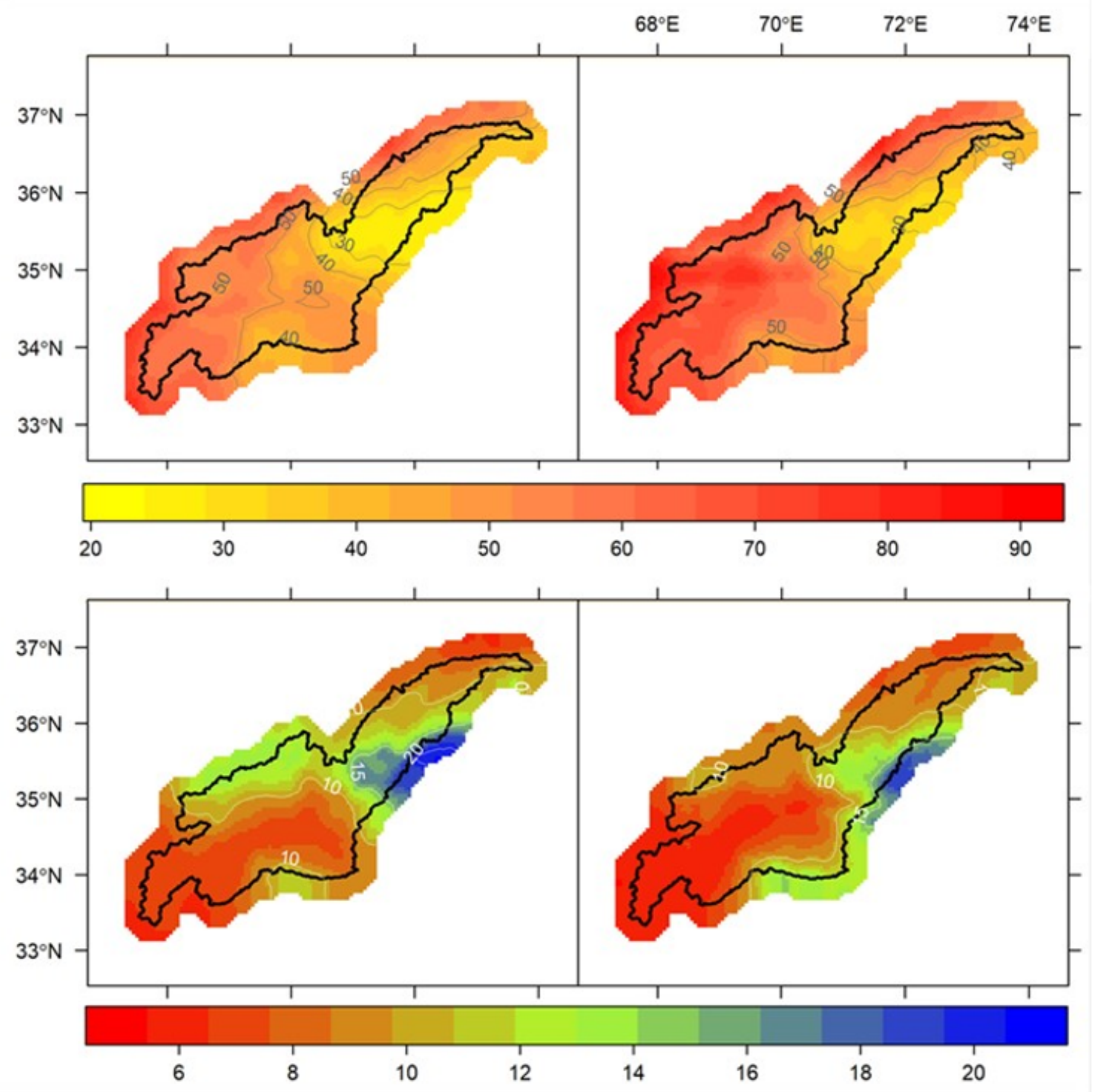

Figure 8

The annual changes in Consecutive Dry Days (upper panel) and Consecutive Wet Days (lower panel) during 2071-2100 in two different scenarios. 


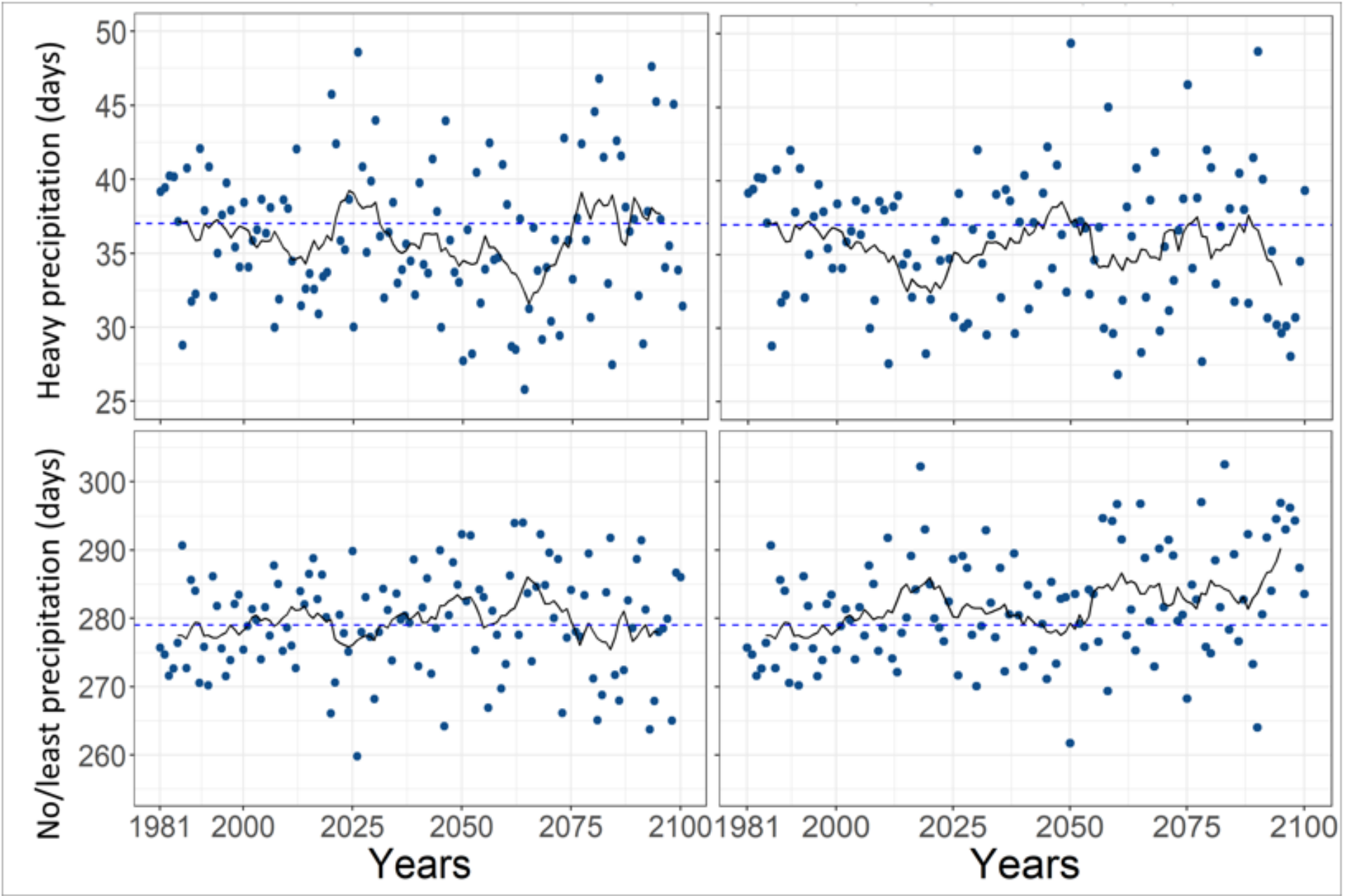

Figure 9

The number of very high (upper panel) and very low precipitation (lower panel) days from 1981 to 2100 in two different scenarios. The black line indicates the 10-year moving average, while the blue dotted line is the average in the baseline period. 